\title{
ELECCIONES Y LECCIONES... ¿QUE PASO EN MARZO DE 1994?
}

\author{
José Francisco Lazo M.
}

L

as elecciones del 20 de marzo de 1994, que sirvieron para elegir a todos los miembros de elección popular que se es tablecen en la Constitución, como son: Presidente y Vicepresidente, Diputados para la Asamblea, Parlamentarios Centroamericanos y Concejos Municipales, contaron con la participación de todo el espectro político, en total contendieron 9 partidos.

La legislación electoral en el caso de presidente, indica que si ninguno de los candidatos logra al menos la mitad más uno de los votos válidos, será necesaria una segunda vuelta donde participen los candidatos que lograron el primero y segundo lugar. El 20 de marzo en los resultados presidenciales, ARENA logró 651,632 votos (49.1\%); la COALICION 331,629 votos $25.0 \%$ ); el PDC 215,936 votos (16.3\%); el PCN 70,854 votos (5.3\%); MU 31,925 (2.4\%); MSN $13,959(1.1 \%)$ y el MAC $10,901(0.8 \%)$ (cuadro $\left.\mathrm{N}^{\circ} 2\right)$. El total de votos válidos fue de 1,326,836; además, la suma de los votos nulos, impugnados y abstenciones llega 104,199 que representan la cuarta votación en importancia, e incluso superan a la votación sumada del cuarto y quinto lugar, PCN y MU.

Por tanto hubo necesidad de una segunda vuelta, el 24 de abril, con dos contendientes: Armando Calderón Sol y Rubén Ignacio Zamora, por ARENA y COALICION respectivamente. En esta ocasión los resultados favorecieron a Calderón Sol con 818,264 votos $(68.4 \%)$ y Zamora quedó con 378,980 votos (31.7\%). Lo cual dejó como Presidente electo al candidato de ARENA. 
En las restantes elecciones los resultados fueron, para diputados de la Asamblea; ARENA logró 605,775 votos (45.0\%); el FMLN 287,811 votos (21.4\%); el PDC 240,451 votos (17.9\%); el PCN 83,520 votos (6.2\%); la Convergencia 59,843 votos $(4.5 \%)$; el MU 33,510 votos (2.5\%); el MSN 12,827 (0.9\%), el MAC 12,109 votos (0.9\%) y el MNR 9,431 votos ( $0.7 \%$ ) (cuadro $\mathrm{N}^{\circ} 2$ ). De estos resultados, !a composición de la Asamblea quedó de la siguiente manera: ARENA con 39 diputados, FMLN con 21, PDC con 18, PCN con 4, Convergencia con 1 al igual que el $\mathrm{MU}$, no lograron escaños el MSN, MAC y MNR. Los veinte diputados al PARLACEN quedaron distribuidos así: ARENA 9, FMLN 4, PDC 4, PCN 1, al igual que el MU y la Convergencia, para este caso la votación es la misma que para la Asamblea Legislativa.

En cuanto a los Concejos Municipales, que en total son 262, ARENA logró 207 (79.0\%); el PDC 29 (11.1\%), el FMLN 13 (5.0\%) la coalición FMLN-CD $2(0.8 \%)$, el PCN $10(3.8 \%)$ y el MAC apenas $1(0.4 \%)$ (cuadro $\left.N^{\circ} 8\right)$. No obtuvieron alcaldías: la coalición FMLN-CD-MNR, la Convergencia, el MU, MSN y el MNR.

En todos los casos, ARENA logró resultados más allá de los que se esperaba, en otras palabras, se creía que estaba más desgastada de lo que en realidad estaba; mientras que la izquierda aparecía como con más posibilidades de lo que en realidad obtuvo; el PDC cosechó lo que sembró, únicamente su dirección mantenía la creencia firme de que continuaban siendo la segunda fuerza electoral en una posición cómoda.

Los resultados vistos de manera fría, nos dejan varias lecciones, entre las que destacan: que ARENA se consolida como primera fuerza político-electoral, que el FMLN pasa a ocupar la segunda posición aunque no consolidada, desde nuestro punto de vista, ya que es poca la diferencia con el PDC (sobre este punto se profundizará más adelante) y la distancia que lo separa de ARENA es grande. El tercer lugar es para el PDC, que pierde por primera vez en su historia de casi 30 años el estar dentro de los dos primeros lugares. El PCN se resiste a desaparecer, pero sigue manteniendo un papel importante en las decisiones legislativas, ya que la suma de diputados del PCN y ARENA garantizan la mayoría absoluta, que es la que se requiere para la mayor parte de las decisiones legislativas, que si bien cierto llegan al mínimo requerido, pero 
resulta ser endeble, ya que apenas logran 43 diputados (en la anterior legislatura lograban 48 diputados), que es la cifra mágica mínima para tener mayoría sobre los 84 diputados que componen al parlamento, decimos que es endeble ya que por tener el mínimo requerido, cualquier cambio que se experimente en la composición de la fracción parlamentaria del PCN deja en serias dificultades a ARENA de conseguir la mayoría, en legislaturas anteriores el PCN ha experimentado escisiones, lo cual es probable que se de en la actual.

Otro resultado es que con la participación por vez primera de dos partidos con tendencia evangelista, MU y MSN, se pudo ver cual es su verdadero caudal de votos. De estos dos partidos, el que salió mejor librado es el MU que logró sendos diputados en la Asamblea y en el PARLACEN; mientras que el MSN perdió su registro al no alcanzar el mínimo de votación que exige el Código Electoral, que es de $1.0 \%$. Sobre este punto es importante destacar que los partidos de tendencia religiosa, cuatro en total, experimentaron retrocesos en su participación electoral, el PDC quedó relegado al tercer lugar, el MU apenas sí logró un diputado, mientras que el MAC y el MSN perdieron su registro.

Un elemento que es necesario destacar, es el papel electoral de los partidos de izquierda democrática, la Convergencia y el MNR. La Convergencia apenas si logró un diputado (en la legislatura pasada obtuvo 8 en las elecciones y tuvo dos adhesiones, para terminar con 10 diputados), el MNR, el partido socialdemócrata con mayor historial (inscrito en 1967, afiliado a la Internacional Socialista desde 1978) no obtuvo resultados favorables, es más su registro electoral se encuentra en discusión por no llegar al mínimo de votos, que requiere la Ley para conservar el registro, en las elecciones de diputados, aunque sí logra superarlo en las elecciones presidenciales, aunque en coalición con el FMLN y la Convergencia, con todo es el partido con más magros resultados en las votaciones.

El MAC, escisión del PDC en 1988, como ya se dijo perdió su registro electoral, es un partido que supo aprovechar su paso por la Asamblea y realizar alianzas con ARENA, en diversas áreas gubernamentales. 
Estos son los resultados fríos, sobre ellos mucho se ha escrito, varios artículos de análisis y reflexión se han realizado, algunos con bastante profundidad y otros más con el propósito de vertir una opinión rápida.

Todo proceso electoral deja una serie de lecciones. Experiencias de aquello que fue positivo, en dónde se tuvieron dificultades y errores, por tanto queda la posibilidad de que en futuros procesos electorales se encuentren mejor preparados los partidos para hacerle frente y poder, de esta manera, obtener mejores resultados.

\section{Las lecciones de las elecciones}

Todo partido político, sin excepción, tiene dentro de sus propó 1 sitos el llegar al poder, ya sea que lo haga por la vía eleccionaria (solo o en coalición) o por la vía violenta (golpe de Estado o revolución). Llegar al poder, para el caso de un sistema político como el salvadoreño, que es por esencia presidencialista, implica no solamente ganar la presidencia, sino asegurarse una adecuada correlación de fuerzas a nivel del órgano legislativo (ya sea con mayoría propia o con mayoría coaligada) y contar con un órgano judicial cercano.

También se tiene que considerar que hay momentos mejores que otros para acceder al poder, no siempre es lo mejor lograr el poder en momentos difíciles. Por ejemplo, cuando hay convulsión social, pobreza, dificultades económicas (caída de las exportaciones, alta deuda externa, inflación, escasez de divisas, etc.), polarización política extrema, etc., las posibilidades de realizar una adecuada gestión administrativa se ven aminoradas. Si por otra parte, se tiene un entorno económico que poco favorece a la implementación de estrategias de las convicciones políticas propias, por ejemplo, los partidos de izquierda, ante el entomo neoliberal (privatización, reducción del papel del sector público, apertura comercial externa, penetración de las empresas multinacionales, problemas de deuda externa, etc.) los deja con serias limitaciones para poder impulsar un plan de gobiemo que responda a sus propias y legitimas convicciones. A este respecto, Francisco Weffort ha escrito que "Para la izquierda en general, esta situación le toca lo más profundo de sus raíces, ya que debe implementar programas de 
ajuste, pero debe tener un horizonte que debe ser definido por un programa que atienda las reformas sociales y la consolidación de la democracia política, ya que la izquierda continúa teniendo una serie de valores democráticos básicos como son: la. reivindicación de la libertad política y la defensa de la igualdad social. Debe tomar en cuenta que las posibilidades de un triunfo revolucionario no se encuentra en el futuro inmediato, además de que el marxismo leninismo se encuentra enterrado como perspectiva histórica, tanto por el régimen político en que se basó estuvo alejado de toda consideración democrática, así como por el hecho de que es antihistórico y contrario al materialismo dialéctico que tanto pregonaron los creadores del socialismo científico, Marx y Engels"2. Se debe llegar a reconocer que el planteamiento marxista-leninista resulta estar distanciado y divorciado de las tesis marxistas. Pero entender ésto y aplicar programas de ajuste, son retos a superar y no tienen que verse como obstáculos insalvables ni como que se ha perdido toda consideración 'revolucionaria' que busque la justicia social.

Si bien es cierto que el marxismo-leninismo se encuentra enterrado, esto no debe preocupar en demasía a aquellos grupos salvadoreños que profesaron dicha convicción, donde muchos dieron hasta su vida por ello. La mayoría, sino es que todos, los actuales miembros del FMLN nacieron bajo dicha ideología y han luchado por ella, pero deben tomar en cuenta que la afectación a sus propósitos se da ante todo en aspectos teóricos, ya que el marxismo-leninismo ha sido ante todo una convicción de tipo ideológico por sobre una consideración de tipo práctico en El Salvador. Por tanto, lo que se encuentra en discusión está en el ámbito de las ideas. Se debe tener presente, con la finalidad de ampliar y enriquecer los elementos de la discusión, que lo que sí ha fracasado en El Salvador es la práctica del capitalismo - el Capitalismo Real- el cual debe ser analizado, modificado y cambiado, dentro de los límites que impone en estos momentos el proceso de globalización.

En 1993 escribimos lo siguiente: “El presente año (1993) se presenta de innumerables retos para todas las fuerzas políticas, sin ninguna excepción. Cada uno de los partidos políticos pretenderá salir fortalecido de dicha contienda electoral (la de 1994), ya sea 
que logre una importante acumulación de cargos o bien que logre articularse en una adecuada estrategia electoral para conformar gobiernos (Power Sharing) muy de moda en los sistemas políticos europeos, o bien que le sea funcional para desarrollar políticas propias con la finalidad de desarrollarse con vuelo propio en una proyección de mediano plazo.... Además, hay que tomar en cuenta que la sociedad salvadoreña todavía se encuentra por afirmar uno de los objetivos fundamentales para lograr su total reconciliación, tal como lo dijera el Secretario General de la ONU, Boutros Boutros Ghali, (el 15 de diciembre de 1992, cuando se celebró el fin formal del enfrentamiento armado): EI propósito del proceso (de negociación bajo los auspicios de la ONU) era ponerle fin al conflicto armado por la vía política lo más rápido posible, promo ver la democratización el país, garantizar el respeto irrestricto de los derechos humanos y reunificar la sociedad salvadoreña. . . El primer objetivo se ha alcanzado. . . Se han dado muchos pasos para el logro del segundo objetivo, que es promover la democratización del país. Pero todavía faltan muchos. . La vigilancia del respeto a los derechos humanos es un elemento del trabajo de la ONU en El Salvador... Este tercer propósito se está consolidando gradualmente'. Respecto del cuarto gran objetivo, Ghali se refirió de la siguiente manera: ... todavía no se avisora. Las cicatrices del pasado se encuentran presentes. Es esencial que aquellos en posiciones de responsabilidad jueguen un papel importante en curar las heridas... La reunificación de la sociedad es un objetivo a largo plazo. No sobrevendrá por milagro. Las partes en el acuerdo de paz deben dar el ejemplo cumpliendo sus solemnes compromisos. También deben desempeñar un papel activo en la promoción del proceso de distensión y reconciliación"

Y seguíamos diciendo: "De ello se deriva que cada fuerza política debe comprender que para el periodo presidencial que se inicia en 1994, todavía habrá que impulsar este cuarto objetivo, eso significa que la actuación gubernativa de quienes estén al frente del gobierno debe estar signada por este magno objetivo. Es por esta razón que creemos que nadie podrá impulsar un modelo de acuerdo con sus propios intereses, sino que habrá que privilegiar la búsqueda de un amplio consenso nacional." 
La particularidad de las elecciones de 1994, se centraba en que la fuerza ganadora debería contar con el mayor nivel de respaldo posible, tanto de sus partidarios, como de sus adversarios, dado que lo que estaba en juego era la reconstrucción nacional, que implica no sólo levantar lo destruido durante el conflicto, sino también el sentar las bases que garanticen el desarrollo socio-económico de El Salvador. Este proceso no puede ser responsabilidad de un determinado sector nacional, sino que es y debe ser responsabilidad nacional, lo cual implica un mínimo de consenso en tomo a dicho tema, en otras palabras, constituye una política de Estado y no una simple política gubernamental.

Es por ello que en las elecciones lo que se puso en discusión consistió en determinar ¿Cuál fuerza política contaba con mejores simpatías para llevar adelante el proceso de reconstrucción y el de lograr una adecuada reunificación de la sociedad? Este era el reto, hacia ello se debían haber enfilado las propuestas programáticas y el entorno de la campaña electoral.

Esta última situación es concordante con las encuestas del IUDOP, que en febrero de 1994, expresaban lo siguiente: "...Los resultados muestran que no hay problemas nuevos, las dificultades que citan son la mismas que les vienen preocupando (a los encuestados) desde el fin de la guerra (refiriéndose a encuestas anteriores). La delincuencia, la crisis económica, la pobreza, la inflación, el desempleo se encuentran entre los principales problemas del $86.5 \%$ de los encuestados. La delincuencia tanto como la economía continúan siendo los principales problemas del país. . (un análisis por sectores arroja que) las personas de los sectores más acomodados hablan más de crisis económica, un término bastante genérico que denota la percepción de que algo anda mal en la economía; en cambio, las clases medias y, sobre todo, los sectores más pobres se muestran muy sensibles hacia la pobreza. . . Otra consideración muestra que la delincuencia constituye un problema mayúsculo entre los seguidores de ARENA, mientras que los seguidores de la Coalición de izquierda se presenten como los menos preocupados por la actividad de los ladrones. En general, los electores de los partidos de oposición atribuyen mayor importancia a los problemas de índole económica. ${ }^{15}$ 
La misma encuesta arrojó los siguientes resultados referente a que si se estaría de acuerdo con que ARENA continuara gobernando o si de nuevo llegara el PDC o si el FMLN lo hiciera. Por ARENA se pronunciaron con Sl, el $46.5 \%$ de los encuestados y con NO el $36.1 \%$; por el PDC que Sl el $28.7 \%$ y con NO $50.0 \%$; por el FMLN que Sl el $28.2 \%$ y con $\mathrm{NO}$ el $48.3 \%$. Esto es indicativo de que para el electorado, el partido ARENA era el que debía ganar las elecciones, mientras que el FMLN y el PDC no tenían los créditos suficientes. En otras palabras, dentro del grueso del electorado, ARENA era considerado como el partido que mejor podía llevar adelante los retos de la reconstrucción y de la reconciliación.

Algunas de las explicaciones sobre este comportamiento pueden ser: por el lado económico, que los empresarios, que en su mayor parte son areneros, son los que están mejor preparados en este campo de acción; el PDC ya fracasó y el FMLN no está preparado para ello; por el lado de la reconciliación, ARENA fue el partido que firmó la paz, situación que logró capitalizar a lo largo de la campaña, en cuanto al PDC se mantiene que no gobernaron bien cuando estuvieron en el poder, al FMLN se le atribuye que fueron los "terroristas", los que posibilitaron que hubiera guerra. Shafick Handal al referirse a esta situación indica que: "ARENA hizo una campaña enfatizando en hechos de la guerra y colocándonos a nosotros (FMLN) como los terroristas, los agresivos, gente a la que hay que tenerle miedo"6. Además, en la campaña se firmaron ciertos pactos políticos que enfatizaban en que fuera una campaña sin insultos, sin recriminaciones, sin ataques al adversario, esta situación le sirvió de maravillas a ARENA y le perjudicó seriamente al FMLN y al PDC, quienes no pudieron poner contra la pared a ARENA. Mientras que en el grueso de los votantes quedó la idea de que el PDC es corrupto (las campañas de 1988, 1989 y 1991 enfatizaron estos términos) y el FMLN es el partido de los terroristas. ARENA quedó limpia, es decir sin ser los escuadroneros, los militaristas, los que descapitalizaron el país, y hacedores de la guerra.

Así las cosas, todo estaba preparado para el triunfo de ARENA, en algunas acciones por méritos propios, como fueron: la campaña de televisión que lanzaron, donde hubo unidad temática entre 
el partido, el gobierno y la empresa privada7, el dinero que gastaron en ella fue alto, en televisión se calcula que fueron unos 12.0 millones de colones (1.4 millones de dólares), y en totalidad hay quienes, como ciertos dirigentes, políticos, la calculan en $150.0 \mathrm{mi}-$ llones de colones (17.2 millones de dólares), el llevar candidatos para todos los cargos de elección, el nivel de organización que tienen (hay quienes afirman que es el partido que históricamente en El Salvador, ha contado con el mejor grado o nivel de organización), sus diferencias no afloran al exterior, tienen disciplina (para la determinación de sus candidatos las disputas son internas, 'lavan adentro su ropa sucia'), cuentan con un importante recurso humano (FUSADES, entre otras, es una cantera de cuadros, así como de elaboración de propuestas), etc.

Pero también la oposición le facilitó las cosas, las divisiones internas, las disputas de candidatos, la falta de unidad, la poca creatividad en campaña, fueron no solo discusiones que se dieron al interior de sus estructuras, sino que llegaron a afloran en los medios de comunicación, situación que persistió a lo largo de toda la campaña, aspecto que se repitió en la izquierda, en el FMLN y en el PDC. Situación que debilitó las posibilidades de la oposición.

\section{La propuesta de la Trenza ${ }^{\mathrm{B}}$}

A finales de 1992, se tuvo la idea de articular una propuesta de siglo que se celebrarían en 1994, donde se pondría en discusión la totalidad de los puestos de elección popular. Dado que para cada una de las elecciones la forma de 'ganar' difiere, por este-motivo, se requería articular una adecuada estrategia electoral que garantizara los mejores resultados posibles. La Presidencia se gana con al menos la mitad más uno de los votos válidos, la Asamblea se gana con al menos 43 diputados (gracias a la representación proporcional por cada distrito electoral, la mayoría en la Asamblea no queda garantizada con el hecho de tener la mayoría absoluta de votos) y cada uno de los Concejos Municipales lo gana la planilla que logre el mayor número de votos a su favor.

Con esta diversidad de formas de ganar cada una de las elecciones, se imponía la necesidad de articular los intereses electora- 
les globales, es decir a qué se le apostaba decididamente y qué quedaba en segundo lugar. Por otra parte, las diversas encuestas pre-electorales indicaban que ningún partido político por sí solo podía llegar a gobernar (lograr la Presidencia y la Asamblea, y con ello aumentar las posibilidades de lograr una Corte Suprema de Justicia favorable, ésta es elegida por la Asamblea con el voto de por lo menos dos terceras partes de los diputados, de ternas que le propone el Consejo Nacional de la Judicatura y los abogados de la República). Esta situación era reconocida incluso por el FMLN, cuando afirmaban que "Ningún partido político y ningún sector social por sí solo es capaz de llevar a cabo las profundas transformaciones democráticas que la sociedad demanda para consolidar la paz."

Con la finalidad de conjugar una adecuada estrategia electoral se debía pensar en 'una coalición posible que garantizara un gobierno viable'. En esa ocasión nos aventuramos a indicar que para la oposición en su conjunto era arriesgado el que se obtuviera la mayoría en la Asamblea, la Presidencia y alcaldías claves, dado que con ello se contaría con el poder formal, pero que ello ocasionaría una fuerte oposición del sector económico fundamental, con la misma podría llevar a un bloqueo económico del sector empresarial, lo cual ocasionaría resultados adversos en la gestión gubernamental y que a la larga dicho gane electoral pidiese revertirse en una derrota estratégica para la oposición. ${ }^{10}$ Al PDC, en 1987, ARENA y el PCN le hicieron una huelga parlamentaria y en los Sectores Económicos también hubo paro, se calcula que unas 7 mil empresas y unos $30 \mathrm{mil}$ establecimientos en general protestaron, de manera exitosa, por una medida legislativa que proponía un 'impuesto a la soberanía' que tenía la finalidad de financiar las necesidades que imponía el conflicto armado, impuesto que recaía sobre el gran capital principalmente.

Por ello es que la Trenza se articuló sobre la necesidad de que la oposición se articulara, por oposición política se tomó en cuenta a las cinco organizaciones del FMLN, las tres de Convergencia Democrática, al MNR y al PDC, es decir diez tendencias políticas aglutinadas en cuatro partidos políticos inscritos. La articulación debería consistir en fijarse como meta principal y fundamental el asegurarse la mayoría de diputados, al menos 43. Buscar ganar 
una buena cantidad de Alcaldías, habría que disputarle en este campo la primacía a ARENA (en las elecciones de 1991 logró 165 de 262, dentro de ellas estaban 11 de las 14 cabeceras departamentales). La Presidencia se dejaba como no fundamental de conseguirla.

De esta manera se hizo la propuesta de La Trenza, que indicaba lo siguiente: a) para la Asamblea, en las circunscripciones que eligen tres diputados (ocho departamentos) y en los de cuatro diputados (dos departamentos) lo conveniente era que la oposición llevara dos listas de candidatos; en las que eligen cinco diputados (dos departamentos) y en la de seis, era conveniente presentarse con tres listas; mientras que en la de dieciséis y en la de veinte lo adecuado era presentarse con el mayor número de listas posibles, al menos unas cuatro. Con esta propuesta se garantizaba el mayor número posible de diputados por residuo, gracias a la representación proporcional. Los cálculos indicaban que podrían obtenerse un máximo de 49 diputados y un mínimo de 35.

La estrategia también incluía que para el caso de las Alcaldías, se presentara la oposición con candidatos únicos, ya que de lo contrario se convertían en adversarios; lo mismo debería hacerse en el caso de la presidencia. La propuesta se hizo sobre la base de que "Para las fuerzas políticas opositoras, la fase de transición necesita contar con el aporte de mayorías- bloques-políticas estables, donde predomine el ingenio, la madurez, el realismo y la responsabilidad de todos los sectores involucrados. Se requiere en primer lugar una sumatoria de fuerzas desde el Centro hasta la Izquierda, tal como sucede en COPAZ (Comisión Nacional para la Consolidación de la Paz). En COPAZ, las fuerzas allí representadas forman dos bloques, por un lado, la Convergencia, UDN y el PDC; y por el otro ARENA, MAC, PCN y Gobierno. Cada uno de los bloques es una expresión de la realidad política generada a partir de los acuerdos de paz, que además permite que las decisiones tomadas en COPAZ sean sobre la base de consenso."11

Si en COPAZ, el bloque conformado entre el centro y la izquierda tomaba sus propias decisiones para hacerle frente al otro bloque, ello de por si era indicativo de los vasos comunicantes entre el PDC y el FMLN, por tanto de que tenían intereses conver- 
gentes entorno al desenvolvimiento de los acuerdos de paz, lo cual hacia presagiar la posibilidad de articularse para las elecciones de 1994, que incluyera la implementación de una estrategia coordinada, una plataforma única, ésta era la mayor consistencia que tenía el planteamiento de La Trenza.

Pero no un Proyecto Nacional para Gobernar que era la posición del PDC, que consistía en que ellos se irían separados en la primera vuelta (Presidente, diputados y alcaldes) y que se juntaran hasta la segunda vuelta electoral presidencial, ya que abrigaban la idea de que el PDC era todavía la segunda fuerza electoral a nivel nacional, por tanto se les hacía fácil creer que en la segunda vuelta conseguirían el apoyo de la izquierda. Esta era una lectura equivocada que hacían, ya que ninguna encuesta les daba el segundo lugar. Queda para la experiencia política el no considerar los resultados de los sondeos de opinión, que por lo menos fueron cuatro instituciones las que dieron un seguimiento pre electoral, mismas que iniciaron sus actividades con unos 24 meses de anticipación a la fecha de las elecciones.

Los resultados de las encuestas pre-electorales realizados por el IUDOP de la UCA (cuadro $\mathrm{N}^{\circ} 1$ ), indicaban que desde junio de 1993 ARENA era el partido que contaba con la mayoría indiscutida en las preferencias de los votantes, lo cual se hace más claro al analizar estos resultados de manera ajustada, es decir tomando en cuenta únicamente a aquellos que sí manifestaron su intención de voto. Sobre esta base, ARENA contaba con un porcentaje que le garantizaba una posición cómoda en el primer lugar, sólo en junio de 1993 tuvo un porcentaje inferior al 50\%. El PDC, en junio de 1993 se encontraba ligeramente por arriba de la suma de los partidos de izquierda, pero éstos a partir de octubre se colocaron en un indiscutible segundo lugar, relegando al PDC a la tercera posición.

A partir de los resultados de las encuestas del IUDOP (las restantes instituciones daban resultado con la misma tendencia), era indiscutible que ninguno de los partidos de la oposición por sí solo era un contrincante real a ARENA en lo que respecta la Presidencia, pero si era posible el quitarle la mayoría en la Asamblea - en el caso de las alcaldías este tipo de encuestas poco puede aportar-, para ello era necesario tener conciencia de esta realidad 
y sobre esta base actuar políticamente. Sin hegemonismos, sin mayorías pretendidas o ficticias, sino con patriotismo, es decir, haciendo lo que la razón indica y no lo que dicta el corazón o en el peor de los casos, el hígado.

En diversas sociedades, los partidos han actuado más con el deseo de acceder al poder, anteponiendo para ello desde opciones ideológicas hasta razones meramente prácticas todo por la instauración democrática, tal ha sido el caso de la Concertación Chilena, con el PDC y el PS, además de otros 14 partidos-que fue clave en el NO contra Pinochet-y que ya lleva dos presidentes electos, P. Alywin y E. Frei, situación que ha sido clave en el proceso de reinstauración democrática. También está el caso de la UNO en Nicaragua, que llevando a Doña Violeta de Chamorro logró la presidencia, desplazando de esta manera a los sandinistas; otro caso fue el experimentado en Bolivia, cuando Jaime Paz Zamora hizo alianza con Hugo Banzer - una coalición similar a que fuera entre la Convergencia y ARENA-; se encuentra también el caso de Fernando Cardozo en Brasil (octubre 1994), que gracias a una oportuna política de alianzas, entre otras cosas, logró derrotar al candidato del PT - Lula Da Silva- quien hasta unos tres meses antes de las elecciones las encuestas lo daban como claro ganador, pero fue hasta último momento en que Cardozo logró ganar la simpatía del electorado y resultó electo con más del $50 \%$ de los votos. Mientras que otras realidades indican caminos contrarios, tal es el caso de Corea del Sur en 1987, cuando el candidato oficial, Roh Tae Woo, aceptó contender en condiciones básicamente equitativas. La oposición, sin embargo, presentó dos candidatos con gran arrastre, el oficialismo ganó con el $37 \%$ de los votos y sus dos contendientes que le siguieron obtuvieron 28 y $27 \%{ }^{12}$, de haberse operado una coalición entre el segundo y tercer lugar, de antemano se sabría que el oficialismo hubiese sido derrotado, a través de un gobierno compartido (power sharing). En igual situación se encuentran los dos principales partidos de oposición en México, el PAN y el PRD, donde en uno de ellos, en el PAN se presentan al menos dos grandes posiciones respecto de políticas de alianzas: una pragmática que se caracteriza por ser antipriista por excelencia y que está en disposición de aliarse con quien pueda, con la finalidad de derrotar al PRI, la otra caracterizada como 
más ideológica que es anti-izquierdista y que por lo tanto no está en disposición de coaligarse con tendencias socialdemócratas, caso del PRD, mucho menos con marxistas. En las pasadas elecciones de agosto de 1994 estos dos partidos se presentaron divididos y el PRI salió como espuma, con mayoría absoluta.

La historia es prolija en la presentación de ambos casos: los de éxito de las políticas de alianzas, así como de sus descalabros; también de aquellas situaciones en donde la lógica imponía una política de alianzas, pero ésta no se pudo concretizar por diversos motivos.

En las situaciones donde se 'justifica' una política de alianzas, éstas no aparecen como algo premeditado o con normatividad clara, dado que en muchas ocasiones, sino es que en la mayor parte de las veces que se dan, los partidos tienden a ser pragmáticos en sus coaliciones, esto tiene que ser así ya que se coaligan no solo dos o más partidos, sino ideologías y es en este punto donde surgen las discrepancias mayores, como por ejemplo ¿Cuál ideología predominará en la propuesta programática?.

Cuando los partidos tienen un interés común (impedir que un opositor llegue al poder, tal como fue el caso boliviano), o bien posibilitar un tránsito hacia un proceso democratizador (tal es el caso chileno), la posibilidad para las alianzas se potencia, mientras que cuando no existe ese interés en común, sucede lo contrario. En los regímenes caracterizados por ser parlamentarios, como los europeos, los gobiernos de alianzas están a la orden del día, sólo que en estos casos las alianzas pueden ser pre o post evento electoral, aunque por lo general predominan las alianzas post electorales, situación que se da cuando se conoce la conformación del parlamento, en estos casos le corresponde a la mayoría parlamentaria, y con su adecuada política de alianzas, conformar al nuevo gobierno. En todo caso, se debe tener presente que las políticas de alianza o concertaciones o coaliciones llegan hasta donde la voluntad política de los involucrados permiten que lleguen y que avancen.

En los casos de los regímenes presidencialistas, como los que predominan en el continente americano, a diferencia de los parlamentarios, la política de alianzas o coaliciones necesariamente tie- 
nen que ser previa al evento electoral. Esta constituye una de las máximas dificultades para realizarla, dado que hay que responder a la pregunta ¿Quién es el candidato?, es decir qué partido o fracción será el que lideree la coalición. Por lo general todos los partidos pretenden, con justificado derecho, a que sea su candidato el que sea tomado en cuenta, pero si hay varios en esas condiciones, cómo poder compatibilizar dichos intereses. La experiencia indica varios procedimientos para darle respuesta, ellos pueden ser: la celebración de elecciones primarias o que el partido mayoritario lo decida o que sea una figura política de consenso a las direcciones de los partidos coaligados (puede ser alguien partidario o un 'independiente'). Este es uno de los puntos neurálgicos que dificultan las coaliciones, otro es cuando se elabora el programa de gobiemo a impulsar y cuando se decide la distribución de cargos en el gabinete y de otros puestos públicos.

Por lo general, son los partidos mayoritarios los que tratan de imponerse por sobre los de menor tamaño, pero cuando no se sabe con certeza quién es el más grande, tal como fue el caso salvadoreño, donde el PDC, al menos su máxima dirigencia, creía firmemente que eran la segunda fuerza electoral y por tanto pretendían, en caso de una coalición de la oposición, tener una participación mayor; pero también en el caso de los partidos de extrema izquierda o dogmáticos se opera una suerte que dificulta las coaliciones, que tiene su origen en la concepción doctrinaria de su origen, desde sus inicios, todos los partidos dogmáticos se autodefinen como la vanguardia, los poseedores de la verdad - los iluminados o elegidos para conducir los destinos de un pueblo-, lo cual lo traducen en posiciones de hegemonismo ante los pactos de coalición, el problema se agrava si son varias las tendencias de izquier$\mathrm{da}$, donde cada una se cree portadora de la verdad. En muchas ocasiones, los posicionamientos y las trincheras que cada fuerza política tiene, dificultan los pactos de coalición. Se viene al caso, aunque se desconozca la realidad de lo acontecido, que lo que privó la posibilidad de un pacto de coalición en el caso de Corea del Sur, fue que cada uno de los dos opositores se creía que su partido era superior al de su posible coaligante y por tanto merecedor de la candidatura, al final ninguno de los dos obtuvo algo y fue el pueblo coreano el gran perdedor. 
Ante esta situación debe prevalecer la cordura, la discusión seria y patriótica, se debe pensar mas en qué es mejor para la sociedad y no en personalismos o partidismos. Pero en este pensar qué es mejor, no se debe ser maximalista, no se crea que es un asalto al 'palacio de gobierno', por tanto debe prevalecer un ambiente de concertaciones, pero más aún de concesiones. Pero ante todo debe tenerse un sentimiento de humildad y no creerse portador de la verdad y de las fórmulas mágicas que le darán solución a todos los males que aquejan a una determinada sociedad.

\section{La participación de la oposición en las elecciones de 1994}

Tl inicio de la campaña electoral, en noviembre de 1993, encon L tró a la oposición y en concreto a la izquierda en una situación de debilidad, por un lado la coalición del FMLN y de la Convergencia para las elecciones presidenciales se había concretado, al menos en el entendido de que así se haría, pero la Convergencia tenía que resolver un problema interno y es de que el Código Electoral permite la coalición de partidos políticos, y en ese momento la Convergencia estaba formada por tres partidos legalmente inscritos, tomando en cuenta que el cierre de inscripción de coaliciones electorales, era de tres meses previos a la celebración de las elecciones, concretamente el 20 de diciembre de 1993, era necesario e indispensable que la Convergencia se fundiera como un solo partido. Durante todo el año de 1993 los diversos institutos políticos estuvieron discutiendo sobre sus posibilidades de alianzas.

El primer partido que se lanzó fue el MNR, en marzo, que propuso a su entonces secretario general, meses antes este instituto había decidido salirse de la coalición de Convergencia Democrática (MPSC, PSD y MNR), dejando de esta forma el camino libre para que la UDN, partido que había roto sus vínculos con el PC, ingresara en la Convergencia.

En mayo, la Convergencia junto con las FPL deciden unilateralmente impulsar la candidatura de Rubén Zamora y Facundo Guardado. El PDC decide que sus candidatos serán determinados a través de elecciones primarias ${ }^{13}$, para presidente se presentaron dos candidatos, Fidel Chávez Mena (en su tercer intento consecu- 
tivo por lograr la presidencia) y Abraham Rodríguez (candidato presidencial en 1967). Logró imponerse Fidel Chávez.

Al interior del FMLN, la decisión unilateral de las FPL de apoyar la candidatura de Rubén Zamora generó ásperas discusiones y acusaciones de hegemonismos, imposiciones madruguetes, etc., situación que trascendió hasta los medios de comunicación. En esta discusión se encontraban, cuando a finales de mayo se dio un caso fortuito, estalló en Managua un depósito (buzón) de armas, propiedad de las FPL, que contenía gran cantidad de armamento, incluso misiles tierra aire, fuera del inventario presentado a la ONU, hecho que fuera calificado por el Secretario General de la ONU como la peor violación ocurrida a los Acuerdos de Paz, esta situación debilitó la posición de las FPL, por lo que decidieron retirar la candidatura de Facundo Guardado, pero siguieron apoyando la de R. Zamora y lograron en ésto el apoyo de otras dos organizaciones del FMLN, tal fue el caso del PC y del PRTC. Mientras que las restantes organizaciones, la ERP y la RN, estaban por ampliar el expectro político de las posibles alianzas, y se definían por una candidatura como la de Abraham Rodríguez. El bloque de las FPL, PC y PRTC tenían la propuesta de impulsar candidaturas a presidente de personas que provinieran de la izquierda, mientras que la ERP y la RN consideraban que se debería ampliar el espectro ideológico de los candidatos. Al final se impuso el 3 a 2 y las candidaturas recayeron en R. Zamora y en el abogado Francisco Lima, éste último ya había sido Vicepresidente de la República, de 1962 a 1967 en el inicio del partido PCN; a principios de los 80 's fue un duro crítico de las acciones de la guerrilla, personificada en el FMLN, además es un empresario de regular éxito, pero que en los últimos años se constituyó en uno de los más acérrimos críticos del gobierno de ARENA, al que atacó por actos de corrupción (lo más seguro es que éste haya sido el mayor mérito que le valió el apoyo del FMLN para ser candidato a Vicepresidente).

En el PDC la nominación de Fidel Chávez imposibilitó la oportunidad de lograr una candidatura única de oposición para la presidencia; al igual que dificultaba esta situación la posición del bloque FPL-PC-PRTC. 
Los tres partidos coaligados en Convergencia, impulsados más por conveniencia política, que por convicción, decidieron fundirse en un solo partido, que se llamaría Convergencia Democrática, dejaron de existir como partidos el MPSC, la UDN y el PSD, aunque a su interior continuaron como tendencias, con un claro predominio del MPSC, en menor medida la UDN y casi sin capacidad el PSD, que en la práctica terminó subsumido al MPSC. La decisión de fundirse de estos tres partidos obedeció a que su presencia en la Asamblea Legislativa fue bajo la divisa de Convergencia y cada uno de ellos, en la práctica, había perdido su identidad con su propia divisa, pero además el Código Electoral es claro al indicar que únicamente los partidos inscritos podrán pactar coaliciones, por tanto de darse una coalición entre los tres partidos de Convergencia, ésta como tal no podría pactar otra coalición más amplia con el FMLN, por tanto se caería la candidatura de $\mathrm{R}$. Zamora. Por esta razón, en diciembre, a casi última hora, el MPSC, la UDN y el PSD deciden fundirse.

El MNR continuó con su desatino. Después de lanzar a su candidato, pretendió unirse al PDC, en octubre se encontraban muy adelantadas las negociaciones pero éstas fracasaron y se rompieron a inicios de noviembre, a mediados de este mes se decidió por impulsar sus propias candidaturas a todo nivel, dando por sentado que ya no haría ninguna alianza, pero la sorpresa fue mayúscula cuando a escasas horas de que venciera el plazo de cierre de coaliciones, el 19 de diciembre se firmó el Pacto de Coalición Presidencial MNR-CD-FMLN. Se dice que en ocasión de asistir a la invitación hecha por el PRI de México al 'destape' de su candidato presidencial, el 28 de noviembre, el Coordinador del FMLN convenció al Secretario General del MNR para que se aliaran en apoyo de la candidatura de R. Zamora. A la par se firmaron otros pactos focalizados, con el propósito de impulsar candidaturas únicas a ciertas alcaldías. En este caso la dispersión fue más que errática, los tres partidos impulsaron candidatos únicos en sólo seis municipios; la fórmula MNR-FMLN en once; la CD-FMLN en cincuenta y dos, en los restantes municipios fueron como rivales.

A nivel de las listas de candidatos a diputados, las posibilidades de alianzas fueron nulas, cada uno de los tres partidos de izquierda, FMLN, Convergencia y MNR, presentaron sus candi- 
daturas por separado, es decir lejos de toda la lógica que indicaba LA TRENZA ${ }^{14}$. Resulta sorprendente ver cómo es que se dió este nivel de desatino, que fue más una decisión del FMLN, que de los otros dos partidos ${ }^{15}$. Situación que tampoco estuvo ausente de serias dificultades; una de las disputas fundamentales que se dio al interior del FMLN consistió en cómo se repartirían las candidaturas, es decir cuántas le corresponderían a cada organización; otra disputa que se dio fue de entre quiénes se selecionarían los candidatos, también sobre qué estructura recaería la determinación de los candidatos.

En el caso de diputaciones, de acuerdo con cálculos que habían realizado, esperaban una cantidad aproximada de dieciocho puestos seguros. La primera disputa se dio entre las cinco organizaciones del FMLN, cada uno pretendía la mayor proporción posible, aunque se desconoce sobre las discusiones que se dieron al respecto, se puede intuir lo siguiente: se tomaría en cuenta el nivel de presencia y de historia en cada departamento, la ERP exigió que únicamente ellos llevarían candidatos en el oriente del país, situación que se evidencia por el hecho de que todos los diputados electos en esa región le pertenecían. Chalatenango, La Paz y La Libertad fueron para las FPL. Cuscatlán para la RN. San Vicente para el PRTC. En los restantes departamentos la decisión se dio mas que todo por quién tenía un buen candidato, pero no por su presencia histórica, tal como fue el caso de a Ahuachapán para las FPL, Santa Ana para el PC, Sonsonate para el PC. Mientras que en San Salvador y en la Plancha Nacional la decisión fue en base a un reparto de puestos, éstos fueron asignados de acuerdo con el siguiente orden: en San Salvador RN, FPL, PC, PC, PRTC; en la Plancha PRTC, ERP, FPL, RN, FPL. En estos dos casos el orden implica mayores posibilidades de conseguir una diputación, y por tanto, una definición clave era conseguir uno de los primeros lugares en las listas.

Una vez resuelto el reparto de las diputaciones entre las cinco organizaciones del FMLN, el paso siguiente se dio al interior de cada organización, es decir qué espacio u oportunidad iba a tener el movimiento social adscrito a cada organización. Muchas organizaciones sociales reclamaron un legítimo derecho de estar presentes en las decisiones de candidaturas, en contraposición con el de- 
recho reclamado por la estructura político-militar que es la que conforma la mayoría de las estructuras de dirección de cada una de las organizaciones. Al final la mayoría de las candidaturas se definieron por la estructura partidaria, en algunos casos la situación se tornó problemática, tal como fue en Usulután, donde la estructura partidaria impuso a las bases el candidato a diputado, y estas reclamaron el derecho de colocar a todos los candidatos a los Concejos Municipales. "En la mayoría de municipios del país el tipo de candidato del FMLN, seleccionados casi todos más por su trayectoria militante en las organizaciones, que por su reconocimiento entre los habitantes de las localidades por cuales eran candidatos..." 16 Esta situación redujo las posilidades de votación para el Frente, ya que los candidatos al provenir de su estructura armada, uno de los puntos básicos, que ofrecían sobre sus curriculums eran sus proezas de tipo militar; por ejemplo en los mitines decian: jeste compañero en varlas ocasiones liberó a este pueblo, condujo las tropas liberadoras que sacaron a los esbirros del ejército! Era una situación que de cara al habitante común y corriente le era totalmente adversa, ya que identificaba al candidato a alcalde propuesto por el FMLN no como al liberador, sino como al que lo mantuvo con zozobra durante la 'toma o liberación' del poblado, lo cual le debe haber implicado pasar debajo de la cama, sin comer él y su familia durante varias horas, sino que días; por tanto el no votar por este candidato era una forma de manifestar su resentimiento. Con este tipo de candidatos, el FMLN lo que logró fue asegurar lo que ya tenía seguro, pero difícilmente la traería otros sectores no tan comprometidos, recibiendo de esta manera un cierto voto de castigo.

Además se repartían por cuotas las candidaturas de los concejos municipales, en no muchas ocasiones a lo largo de la campaña se operaron reacomodos en dichas cuotas, lo cual generaba una serie de movimientos en diversos lugares. Por ejemplo se dio el caso de un departamento donde ya se tenía el reparto de todos los concejos municipales, pero por alguna razón dos organizaciones se ponían de acuerdo para realizar algún tipo de cambio en un municipio y ésto generaba una serie de reacomodos en el resto de municipios, dizque para mantener el 'equilibrio' en la distribución de puestos, esta situación generó fricciones al interior del 
FMLN, más que todo a nivel de mandos medios y de bases.

Por el lado del PDC, su dirección manifestó la decisión de que no se aliarían con el FMLN en ninguna de los tres tipos de elecciones. Entre septiembre y octubre, las pláticas con el MNR estuvieron muy encaminadas en lograr algún tipo de alianza, pero ésta no pudo concretizarse, más que todo por las divisiones internas de las diversas fracciones democristianas que reclamaban cuotas de candidaturas; en este caso se habló de tendencias fidelistas, que hegemonizaban, y las abrahamcistas que exigían participación. Para darle cabida a los grupos abrahamcistas se dejó de lado la posible alianza con el MNR, partido que sí había insistido en concretizarla, ya que sus dirigentes fueron los que más divulgaron la idea de que estaban en pláticas adelantadas y en más de alguna ocasión hasta llegaron a adelantar que a principios de noviembre se firmaría el pacto.

Como puede apreciarse, la izquierda como un todo careció de una política de alianza, no se puede hablar de que hubo una coalición de izquierda, sino de una fragmentación incoherente, inconsistente, inadecuada que generó un sentimiento de fragmentación cercana al divisionismo, esto a todo nivel, desde la izquierda en conjunto, cada uno de los partidos por separado e incluso al interior del FMLN. En resumidas cuentas, sólo se coaligaron para las elecciones presidenciales, que además se sabía de antemano que no se iban a ganar, para diputados se fueron en rivalidad, al igual que en la mayoría de concejos municipales.

La dispersión de la izquierda, se puede apreciar en las diversas campañas que se presentaron en televisión, que fueron varias y por si fuera poco, sin coordinación, se mencionan las siguientes: "Central Coalición (para presidente), genérica del FMLN, Schafik (alcalde FMLN), Schafik (coordinador FMLN), La Convergencia (alcaldes y diputados), Mujeres Coalición, Mujeres FMLN."17 El MNR no realizó ningún tipo de campaña publicitaria en los medios de comunicación. Para colmo de males, a R. Zamora en sus mítines como candidato a presidente de la coalición tenía prohibido, de parte del FMLN, hacer campaña a favor de los candidatos a diputado y a alcaldes de su partido, la Convergencia.

Además de la dispersión de diversas campañas, se produjo otra 
serie de disputas entre los partidos de izquierda, la de los diversos logos, que implicaba hacer un llamado a los votantes para que marcaran un determinado logo en la papeleta de votación. "Generando una verdadera guerra de logos... Cuando la Coalición se constituyó, los tres partidos asociados intentaron ponerse de acuerdo en el logo conjunto. En vez de adoptar un símbolo unitario, optaron por intentar meter en un pequeño rectángulo las banderas de los tres socios. En esta decisión pudo influir el hecho de que los tres partidos aliados para la elección presidencial competían por separado en las elecciones para diputados y alcaldes. Así, pues, los votantes de izquierda tenían cuatro logos a los que prestar atención: el del FMLN, Convergencia Democrática y MNR por separado y el conjunto formado por las tres banderas." ${ }^{\prime 18}$

Todo ello indica un alto grado de inexperiencia en este tipo de aspecto de las campañas políticas: "Las personas que trabajaron en la campaña de la Coalición confiesan sin rubor que pagaron la novatada. Tan sólo algunos dirigentes de la Convergencia tenían las ideas claras sobre lo que significaba una campaña electoral. La gran mayoría de las personas del equipo de decisión técnico y político aprendió equivocándose." ${ }^{19}$

Por si la situación de dispersión no fuera poca cosa, también se dieron otros hechos. "Falta de programa. A la hora de constituirse la Coalición confluyeron (diversos) programas de gobierno 'de izquierdas', pero con estrategias de gestión política distintas. Hubo que hacer un esfuerzo para encontrar puntos en común y establecer una plataforma programática conjunta. En voz baja algunos miembros del equipo de campaña confiesan que esta plataforma tenía lagunas y que nunca llegó a ser un programa de gobierno." ${ }^{20}$ Los diversos programas que se conocieron al menos fueron los siguientes: el de las FPL, el de la Convergencia, el del FMLN, el de CD-FMLN y el de MNR-CD-FMLN. Para colmo de males, la estrategia más elaborada se presentó después de la primera vuelta, es decir que para las elecciones del 20 de marzo no se contaba con una plataforma consensuada ni integrada.

Toda esta dispersión, por no decirle relajo, en las campañas de la izquierda generó un sentimiento negativo en la población "Diversidad política (la caracterizó). . . Para ganar unas elecciones es 
imprescindible que la población confie en la capacidad de gobernar del candidato y del grupo que lo apoya. La campaña de la izquierda fue incapaz de comunicar este sentimiento de confian$\mathrm{za}^{.21}$

La diversidad de posiciones de la izquierda es uno de los principales aspectos que explican este desbarajuste, la izquierda está lejos de mostrarse unificada, en forma monolítica, a su interior hay fuerzas centrípetas pero también las hay centrífugas que se encuentran interactuantes en forma dialéctica, en algunas ocasiones las fuerzas centrípetas se han impuesto, tal como fue en los años de 1979 a 1988 donde la alianza FDR-FMLN logró aglutinar a todas las tendencias de izquierda, a partir de 1989 esta situación fue perdiendo fuerza y las fuerzas centrífugas tuvieron un mayor dinamismo, hasta llegar a 1994 donde todo parece que han logrado ser mayores que las centrípetas, pero a este aspecto se le dedicará un análisis por aparte. Para las elecciones de 1994, la izquierda contaba con nueve tendencias, cada una con sus intereses, posibilidades, realidades y aspiraciones: cinco en el FMLN, tres en la Convergencia y el MNR por su lado. En el campo ideológico van desde posiciones cercanas al marxismo-leninismo (que en estos momentos se encuentran en grave crisis de identidad, producto de la caída del socialismo real), exmarxistas-leninistas (buscando un reacomodo socialdemócrata), socialdemócratas (en crisis de existencia, ocasionada por la posibilidad de pérdida de su registro, además de otra serie de dificultades, como el hecho de que su actual dirigencia está disociada de lo que fue su tradición con Ungo y Oquelí, la mayoría de sus más cercanos colaboradores fueron expulsados) y socialcristianos (con crisis de identidad, entre el socialismo, la socialdemocracia y la democracia cristiana popular). Una diversidad tal no puede generar otra cosa más que la que generó durante la campaña electoral de 1994.

Si la izquierda no logró un pacto de coalición global entre sí (ante lo expuesto aquí es difícil afirmar que hubo una coalición de izquierda), a diferencia de otros artículos escritos por diversos autores $^{22}$ que han analizado la participación de la izquierda en estas elecciones, donde se refieren ante todo a la coalición, en este punto discrepamos con dicha terminología y más nos acercamos a decir que hubo dispersión en la izquierda en lugar de coalición. 
Ante la dificultad interna de la izquierda, resultaba poco probable el poder concretizar un pacto electoral con la Democracia Cristiana que proviniera desde la izquierda, de igual manera resultaba complicado desde la posición de la Democracia Cristiana, con esta situación se pretende descartar la posibilidad de que Abraham Rodríguez, en el caso de que hubiese ganado las elecciones primarias del PDC, pudiese haberse convertido en un candidato único de oposición. Esta resultó ser una posibilidad teórica, pero difícil de concretarse en la realidad, privaron más intereses particulares por sobre intereses patrióticos, esta es una responsabilidad que recae sobre todos los dirigentes políticos de la oposición. La Trenza, por estas consideraciones realizadas, nació muerta.

\section{Breve historia del centro e izquierda políticos}

na de las particularidades de los partidos o movimientos de
oposición salvadoreña, es que se ubican desde el centro a la izquierda, mientras que por lo general las posiciones dominantes en la esfera gubernamental han sido de las derechas. Al tomar el período que inicia en 1931 se observa que los presidentes han sido si no militares, por lo menos civiles propensos al esquema militarista; el partido PCN gobernó a partir de 1962 hasta 1979, llevando a militares a la presidencia. El golpe de estado de 1979 -hace quince años- inició una nueva etapa, si bien es cierto que los militares no son desplazados, sí se disminuye su influencia en las esferas gubernamentales; de octubre de 1979 a mayo de 1982 gobernaron juntas de gobierno cívico-militares con influencia de la Democracia Cristiana en su mayor parte, salvo durante los tres primeros meses que contó con cierta presencia popular. De mayo 1982 a junio 1984 gobemó una Asamblea Constituyente, con un Ejecutivo determinado por ella. De junio de 1984 a junio 1989 gobernó el democristiano de N. Duarte. En junio de 1989 iniciaron los gobiernos de ARENA, primero con Cristiani, que finalizó en junio de 1994 y le traspasó a Calderón Sol, que gobernará hasta 1999.

Dentro de la oposición, la organización que tiene mayor historial es el Partido Comunista (PCS), cuenta con más de 60 años de existencia, en su mayor parte como organización proscripta por la ley. Le sigue el Partido Demócrata Cristiano (PDC), que nace en 
1960 y se mantiene dentro de los dos principales fuerzas políticas eleccionarias hasta las elecciones de 1994, que fue desplazado al tercer lugar. El tercero en antigüedad es el Movimiento Nacional Revolucionario (MNR), de tendencia socialdemócrata, fue inscrito en 1967 y en 1978 ingresa como miembro pleno a la Internacional Socialista. En 1968 inicia actividades la Unión Democrática Nacionalista (UDN), como partido de fachada legal del PCS.

A inicios de la década de los 70 , surgen las primeras organizaciones político-militares, las Fuerzas Populares de Liberación (FPL) y el Ejército Revolucionario del Pueblo (ERP), la primera como clara escisión del PCS, que no compartía la estrategia electoral de éste, la segunda como producto de una radicalización de jóvenes demócrata cristianos y contando con influencia del PCS. Estas dos nuevas organizaciones se plantearon la lucha armada como estrategia para alcanzar el poder, negando la vía eleccionaria, a diferencia del PCS que mantenía una posición institucionalista a través de las elecciones, razón por la cual este partido se fracciona a finales de la década de los 60 e inicios de los 70 (gráfico $\mathrm{N}^{\circ} 1$ ).

En 1975 se produce la primera escisión en una organización guerrillera, en el ERP, luego de una disputa interna por línea a seguir -entre la posición tradicional militarista y la que buscaba una acción de masas-, que terminó con la muerte del poeta Roque Dalton y de otros miembros; surge de esta manera la Resistencia Nacional (RN). En 1977 surge del seno de la RN el Partido Revolucionario de los Trabajadores Centroamericanos (PRTC), que se plantea un trabajo a nivel centroamericano, es decir trascendiendo el territorio salvadoreño, juntamente con otras organizaciones del mismo nombre en otros países.

A lo largo de la década de los 70, la realidad de las organizaciones político militares fue de disputa entre sí, llegando a casos extremos. En algunas ocasiones una organización dictaba pena de muerte contra miembros de otras organizaciones, por considerarlo traidor. También tenían disputas ideológicas intrascendentes, por ejemplo, si la situación debía de definirse como una escalada militar fascista o si era fascistoide o si se trataba de una dictadura militar o si era dictadura militar oligárquica, lo cual ocasionaba serias discusiones, muchas de ellas bizantinas, que al final imposibilitaban el ponerse de acuerdo. También es de mencionar las 
disputas en torno a la política universitaria, donde los movimientos estudiantiles afiliados a cada organización realizaban luchas, en el sentido estricto de la palabra, por el control de diversos gobiernos universitarios. Cada una de ellas, pero a diferente nivel, realizan durante estos años un importante trabajo de masas vinculado estrechamente con las organizaciones populares.

Las divergencias entre las diversas fracciones de la izquierda, nacen de los planteamientos que cada una de ellas hace respecto de "contar con una concepción política revolucionaria... una estrategia, una táctica, una estructura orgánica y un programa, todas ellas elaboradas a partir del análisis dialéctico de la formación económico-social... (de la sociedad que se pretende modificar)... La estrategia debe dar respuesta al tipo de revolución necesaria y a cómo deba impulsarse en cada etapa histórica. La táctica debe indicar cómo impulsar la lucha concreta en cada período histórico. La estructura orgánica debe mostrar cómo organizar y hacer funcionar el movimiento revolucionario en sus distintos niveles... (finalmente). El programa señala el tipo de sociedad por la cual se lucha.... (Las diferencias que presentaron al respecto fueron mínimas)... Cuatro de las cinco organizaciones que integran el FMLN, las FPL, el ERP, la RN y el PRTC iniciaron su trabajo político a partir de lineamientos estratégicos de carácter político-militar... En estos lineamientos estratégicos iniciales, considerados en perspectiva (hacia 1985), hay más puntos de vista convergentes que divergentes y los serios conflictos y contradicciones entre ellos a lo largo de la década del 70 pueden explicarse más por las diferencias tácticas y por las desviaciones de ciertas practicas originadas por discrepancias personales, secundarias, que impedían ver los aciertos de los otros... Las estructuras orgánicas pensadas y construidas a lo largo de la década del 70 muestran, al contrario, sensibles diferencias a pesar de estar todas referidas a una estrategia de carácter político militar." 23

Lo anterior repercutió en las posibilidades de organizar el FMLN, que fue una etapa difícil, por ejemplo la pugna entre la $R N$ y el ERP, donde cada una imponía veto a la otra, el sempiterno deseo de las FPL de hegemonizar, la necesidad de que el PRTC cambiara su estrategia centroamericanista, el hecho de que el PCS se definiera por la lucha armada, etc. Fueron situaciones difíciles de 
solventar. En este campo influyeron mucho los cubanos. Por fin el 10 de octubre de 1980 se crea el FMLN como tal, pero muchas de sus disputas, rivalidades, diferencias ideológicas, etc. continuaron latentes. La unión de estrategia fue más una realidad en el campo de lo militar, con muy poco desarrollo en otras áreas.

Un trabajo que merece ser (re)leído en las actuales circunstancias, que dice bastante sobre la disputa en el FMLN, es el del desertor de la FPL, Cmte. Miguel Castellanos, que describe el origen del Frente, las diversas posiciones de cada organización la lucha de intereses, etc. En una de sus partes indica: "En toda la década del 70 los cubanos entregan su apoyo oficial y su reconocimiento sólo al PC; al ver que las FPL se van desarrollando comienzan a tomarlas en cuenta, luego lo hacen con la RN. Creo que si no hubiera sido por los cubanos, específicamente Fidel Castro, no hubiera sido posible conseguir la unidad: el FMLN. No como una cosa orgánica, sino como una unidad frentista. Una unidad orgánica es cuando se fusionan estructuras, objetivos y toda una estrategia y táctica a seguir. Este no es el caso del FMLN, en un frente se plantean sólo coordinaciones, acuerdos tácticos, operativos, cada una de las organizaciones sigue manteniendo vigente sus propias estructuras... (y continúa diciendo sobre los problemas concretos de dirección en el FMLN) en el FMLN las organizaciones que lo integran están en una permanente lucha por el podèr; el que logra hegemonizar y tiene mayor incidencia, hace prevalecer sus planteamientos político y militares, esa pugna es permanente." 24

Y sigue diciendo, respecto del papel jugado por los cubanos en cuanto a proporcionar armas a los diferentes grupos: "No todos los grupos (del FMLN) tenían corredor (referido a la mecanismos para poder introducir armas a El Salvador) pero el que sí los poseía podía maniobrar, por ser aduanero, entonces se quedaba con parte de lo que le tocaba a otro. Hubo momentos en que llegó a haber serias discusiones y fricciones. . . discusiones que dilucidaban los cubanos y los sandinistas, quienes llegaron a amenazar que de continuar con ello pararían el envío de armas... (los que recibieron más armas fueron las FPL y el ERP, pero en un momento decidieron apoyar más al ERP para igualarlo en fuerza con las FPL)... En este momento el ERP era un movimiento inmediatista 
que poco pensaba en cuestiones ideológicas ${ }^{25}$ más de fondo; no eran ideológicamente marxistas-leninistas. De allí que los cubanos pensaran que la mejor forma de agarrar a esta organización fuerte y decidida era comprometiéndola, dándole un trato preferencial en la distribución de armas. No es el caso de Marcial (primer responsable de las FPL) y de las FPL, él es marxista-leninista, sólo que es autónomo (de los cubanos) y trata de atraerse al ERP para conseguir la Comandancia General del FMLN ${ }^{26}$. La RN no era muy confiable, ya que se había separado de ERP, y el PRTC era poco relevante. ${ }^{27}$ Es más llegó un momento, en 1981, que el ERP, el PRTC, la RN y el PC se unieron en un bloque contra Marcial y éste se ve en la necesidad de renunciar a la Coordinación General antes de que formalmente fuera destituido, quedando como un miembro más de la Comandancia General del FMLN, cuando esto sucedió, Marcial, llega a plantear que las FPL deben retirarse del FMLN. ${ }^{28}$

Es más, de los análisis hechos por las FPL, se puede apreciar lo frágil que para ellos era la unificación en el FMLN, en 1982, Cayetano Carpio (Marcial) escribió: "El partido de la clase obrera necesita una sola ideología. Pero real, no sólo en palabras, no solo en teoría, sino también en teoría y práctica: la ideología del proletariado, la ideología del marxismo leninismo [...] El FMLN no es eso y no puede serlo en mucho tiempo. Hay diversas ideologías, incluso que chocan entre sí. No podemos hacernos los tontos, tratando de ignorar que entre el FMLN hay influencia de la democracia cristiana mundial, de la social democracia, y la social democracia viene luchando contra el marxismo desde finales del siglo pasado. Precisamente la social democracia se ha convertido, junto con la democracia cristiana, en los dos pilares fundamentales del sostenimiento del imperialismo francés y del imperialismo italiano. La social democracia fue la sostenedora de los horrendos crímenes colonialistas que esclavizaban a Asia y a Africa. La social democracia es la teoría de la burguesía que trata de endulzarse para poder engañar y subir a su carro burgués al proletariado... Por eso es un frente (el FMLN) y no un partido. $Y$ por eso la marcha hacia la construcción del partido único, a través del FMLN es sumamente compleja. Si nosotros consideráramos que no debemos organizar el partido del proletariado a partir de las FPL, 
porque ya hay un FMLN, nosotros estaríamos cayendo en el más grave error y la más grave interpretación de lo que debe ser la lucha de clases para hacer avanzar los intereses del proletariado. Esa meta errónea nos la trazamos en 1980 (año de creación del FMLN). Por suerte vimos que era idealista, utópica, infantil.... Precisamente por los intereses de la unidad, se necesita de la existencia del verdadero partido comunista de El Salvador. Como no ha existido, en eso estriba uno de los males fundamentales de la unidad y quizás el fundamental." ${ }^{29}$ Por esta razón, Marcial sostenía que el verdadero partido comunista debía ser construido a partir de las FPL y no del FMLN., es más, los estatutos de las FPL, indican que 'el germen del verdadero partido comunista que aspira a encabezar el proceso revolucionario y la construcción del socialismo en El Salvador, deben ser la FPL.

La posición sostenida por Marcial, al interior de las FPL y en el FMLN, le llevó a serias críticas internas en su organización que desembocaron en los tristes sucesos de abril de 1983 cuando en Managua es asesinada la Cdte. Ana María (Mélida Anaya M.), segunda responsable de las FPL, los hechores fueron miembros de las FPL, se acusó a Marcial de ser el autor intelectual del crimen, y terminó suicidándose. A partir de este momento se operó una escisión en las FPL y surgió el Movimiento Obrero Revolucionario (MOR) que se decía era el seguidor de la línea trazada por Marcial (guerra popular prolongada, estilo Viet Nam, no en balde escribió en enero de 1983, el prólogo del libro "CU CHI: el secreto de la derrota de EE.UU. en Vietnam"; según dicen los que lo conocieron muy de cerca, que se consideraba a sí mismo como el Ho Chi Min de El Salvador), lo cual indica que la dirección que se quedó al mando de la estructura de las FPL estaba siguiendo una línea diferente a la trazada por Marcial.

Dejando de lado, por este momento el desarrollo de las organizaciones del FMLN. En las restantes organizaciones de la oposición, vale la pena resaltar diversos esfuerzos conjuntos realizados, uno de ellos es el de la coalición electoral, que entre 1972 Y 1977, impulsaron el PDC, el MNR y el PCS, sui géneris unión de demócrata cristianos, socialdemócratas y comunistas, que se denominó Unión Nacional Opositora (UNO), que en las elecciones presidenciales de 1972, con la fórmula Duarte-Ungo, lograron la mayoría 
de votos a su favor, pero el fraude electoral implementado les negó el reconocimiento del triunfo, en 1977 de nueva cuenta se presentó la UNO a elecciones y el fraude también se hizo presente.

Desde ese momento la lucha electoral entró en crisis de credibilidad y la oposición se planteó otras formas de participación política, en 1979 se creó el Foro Popular, con la participación de los ex-integrantes de la UNO, la adición de universidades, sindicatos, organizaciones populares, la Iglesia, etc., que exigían un diálogo nacional, con el gobiemo incluido. Cuando fue el golpe de estado de 1979, el Foro Popular fue convocado para que participara, el Dr. Ungo fue seleccionado para que fuera miembro de la Junta de Gobierno.

En 1980, el PDC decide apartarse de los esfuerzos conjuntos de la oposición y hace alianza con los militares, con el fin de impulsar una estrategia calificada como reformista-contrainsurgente, es decir, hacerle la guerra en los diversos campos a la alianza FDRFMLN, es decir con quienes en algunos momentos había tenido entendimientos.

El Foro Popular fue la primera instancia donde convergieron en algunos puntos de interés mutuo los partidos legales (MNR, UDN y PDC) y algunas de las organizaciones político-militares, a través de organizaciones de masa que controlaban, mismas que ya se encontraban en las discusiones de cómo integrarse $o$ aliarse entre sí.

En enero de 1980, se crea la Coordinadora Revolucionaria de Masas (CRM), como la unión de las organizaciones de masas de las organizaciones político-militares, en abril se crea el Frente Democrático (FD), conformado por el MNR, el MPSC como escisión del PDC, la Universidad de El Salvador, estudiantes universitarios, profesionales, organizaciones sindicales, etc. Unos pocos días después, la CRM y el FD se alían en el Frente Democrático Revolucionario (FDR), pero éste, a partir de 1982 quedó integrado únicamente por el MNR, el Movimiento Popular Social Cristiano (MPSC) y el Movimiento Independiente de Profesionales y Técnicos Salvadoreños (MIPTES), fue esta última combinación la que se conoce como parte componente de la alianza FDR-FMLN. 
Como dato para ser registrado, está el hecho de que fue tal la rapidez con se dieron estos acontecimientos, de que todos estos pactos y alianzas se hacían sobre la base de la voluntad y el respeto mutuo, por esta razón es que no hubo ningún documento que definiera los términos de la alianza entre el FDR y el FMLN. No fue sino hasta 1986 en que se definieron los términos de ella, luego de no varias crisis suscitadas.

Para poner un tanto en orden los acontecimientos, cuando se definió el contenido programático del Gobierno Democrático Revolucionario (GDR), el lanzamiento lo hizo la CRM el 23 de febrero de 1980, antes de que se constituyera el FD, el FDR y el FMLN. Lo importante a destacar este punto es que fueron las organizaciones de masas de las distintas organizaciones que meses después conformarían al FMLN, las que dieron a conocer el GDR, por tanto este planteamiento fue obra de ellos, sin muchos aportes del MNR y del MPSC (que en esos momentos ni tan siquiera existía como escisión del PDC). Esto significa que el GDR, en la práctica lo fue impuesto al FDR. Mario Lungo ve esta situación de la forma siguiente "El fundamento de la estrategia revolucionaria planteada por el FMLN (GDR y guerra popular revolucionaria) y adoptada por los sectores democráticos (FDR) era la lucha político-militar de las masas populares, siendo dentro de ella la lucha armada la forma fundamental... Los aportes de las distintas organizaciones del FMLN fueron desiguales en el momento de diseñar la plataforma del GDR. Esta limitación fue una determinación histórica que no excluyó el aporte de ninguna de ellas puesto que la constitución de la vanguardia se dio en un proceso de síntesis de la dispersión. La formulación programática no es patrimonio de una organización en particular." ${ }^{30}$ Sobre esta temática, se puede decir que las diversas organizaciones políticomilitares, en su conjunto hegemonizaron sobre los partidos del FDR, desde antes de que éste se constituyera. Desconocemos el tipo de discusión que se dio al interior de las organizaciones político-militares para poder llegar a presentar de manera conjunta el GDR, pero algunas luces hay a este respecto, hechos como la pretensión de las FPL de convertirse en el legítimo partido comunista, que el ERP fuera el ideológicamente menos preparado, la experiencia del PCS, la pequeñez del PRTC, etc. son elementos que cuentan en estos mo- 
mentos de definición y aporte concreto. Mario Lungo, en otro trabajo publicado en 1990 señalaba "No podemos, a pesar de la constación que hoy es unánimemente aceptada, desconocer que la larga lucha por la hegemonía habia cobijado el desarrollo, más en unas organizaciones que en otras, de tendencias hegemónicas, que no aceptando esta realidad y los cambios que ella implicaba, lucharon por el predominio de sus concepciones individuales, y que los restos de ella son aún observables en el momento actual. (pero si el FMLN es visto como un todo como la vanguardia... en este caso)... La vanguardia revolucionaria se construye en un proceso contradictorio a partir de la sintesis de núcleos dispersos de vanguardia que han surgido y se han desarrollado históricamente de manera paralela y separada." ${ }^{\prime 31}$

Respecto de esta alianza, Castellanos la ve de la siguiente forma: "(La alianza) entre el FMLN y el FDR (es) una alianza que no tiene perspectiva alguna de consolidación, porque unos son marxistas-leninistas y los otros de naturaleza democrática... el FDR, en la práctica, ha desempeñado conscientemente el papel de cobertura política al FMLN... para quitarle lo rojizo... pero el FDR, a su vez, quiere valerse del FMLN para aprovechar la instauración y consolidación de un Gobierno de Transición donde ellos tendrían mayor hegemonía." ${ }^{\prime 32}$. A este punto de vista hay que agregarle que la presencia del FDR permitió que la solidaridad en Europa Occidental, Estados Unidos, etc. fluyera con mayor dinamismo, además de impulsar un importante papel diplomático, donde la presencia de los socialdemócratas, concretarmente del Dr. Guillermo Ungo, fue clave para que diversos gobiemos se interesaran en la lucha salvadoreña. En todo caso, la relación entre el FDR y el FMLN no fue una relación de primos interpares, sino que fue de una clara hegemonía del FMLN, relación que también operaba al interior del FMLN, es más, entre ellos se llegó a indicar que las FPL y el ERP eran los 'grandes' y que el PC, la RN y el PRTC eran los 'chicos'; en esta clasificación predominaba el tamaño de cada organización, en todos los niveles, en estructura armada, estructura política, estructura de masas, en lo internacional, etc. En más de alguna ocasión, Joaquín Villalobos manifestó respecto de esta situación que los únicos que podían considerarse como ejércitos eran las FPL y el ERP, respecto del PRTC había dicho que casi ni existía. 
En agosto de 1985, el FMLN decide, unilateralmente, es decir sin consultárselo a sus aliados del FDR, el inicio de un proceso para constituirse en un partido único marxista-leninista (con todas la connotación que en esos momentos implicaba eso de ser un partido único marxista-leninista - negar el juego democrático partidario, ser un partido similar a los que gobemaban en Europa del Este, etc.-), fue esta situación la que obligó a los miembros del FDR a exigirle al FMLN la firma de un pacto de alianza, que definiera dicha relación, que no se había dado en 1980 . Este intento del FMLN de conformarse en un partido único no prosperó, sino que fueron más fuertes las fuerzas centrífugas, es decir las disputas internas entre ellos y todo quedó en buenas intenciones. Sobre este tema Joaquín Villalobos, en 1988, "reconocía que la declaración de la comandancia general sobre el partido único, tenía sobre todo un objetivo táctico, lograr el acatamiento de los militantes de las orientaciones del FMLN en esa coyuntura. A nivel estratégico, no se tenía ninguna formulación y señalaba que lo importante era unir sobre la base de una estrategia de poder, no a partir de una concepción de partido."

Pero esta situación, si bien obligó a definir los términos de la relación, dejó un mal proceder, al año siguiente, en 1987, luego de la declaración presidencial de Esquipulas II, que posibilitó una cierta apertura política en todos los países de América Central, el MNR y el MPSC deciden aprovechar dicha oportunidad y juntamente con el recién creado Partido Social Demócrata (PSD) conforman la Convergencia Democrática (CD). Con lo cual el FDR, si bien continuaba existiendo, se debilitaba como tal y por tanto su vinculación con el FMLN, la CD tenía posibilidades de impulsar acciones propias.

"La Convergencia Democrática, desde sus inicios, en octubre de 1987, definió que su objetivo no era electoral... su razón era... Iuchar por cuatro grandes objetivos:

a) luchar por una solución político negociada al conflicto salvadoreño.

b) lograr la recuperación de la soberanía nacional

c) lograr el establecimiento de una auténtica democracia, y 
d) lograr el establecimiento de una economía al servicio de los sectores populares." ${ }^{\prime 34}$

La pérdida de cohesión del pacto entre el FDR y el FMLN poco a poco se fue dando, Ungo se refería a esta situación como que el FDR se estaba evaporando, pero nadie se refería a esta situación tratándolo como la desaparición del FDR y su suplantación por la CD. La realidad se impuso y cuando la CD decidió participar en las elecciones presldenciales de 1989, llevando a Ungo como candidato, el FMLN tuvo una actuación bastante errática al respecto. Primero, tenían la decisión de sabotear dichas elecciones, al igual que lo habían hecho con la celebradas en 1982,1984,1985 y 1988, que fueron declaradas objetivos militares. Segundo, en enero de 1989 lanzaron una propuesta en la que atirmaban que estaban dispuestos a aceptar los resultados de dicha elección siempre y cuando fueran pospuestas por seis meses y que se comprometían a participar en dicha elección, a través de la $C D$. Dicha propuesta no fue aceptada. Tercero, al no ser aceptada su propuesta, de nueva cuenta el FMLN declaró el sabotaje a las elecciones, lo cual enfrió aun más las relaciones de la vieja alianza con el FDR, a partir de este momento el FDR dejó de ser una realidad y fue suplantado definitivamente por la CD.

La propuesta del FMLN en enero de 1989 estaba sobre la base de que si se permitiera a la izquierda hacer campaña electoral, podrían obtener la mayoría absoluta de votos ${ }^{35}$. Lo cual concuerda con lo dicho por J. Villalobos, en esa ocasión "[Apostamos] a que somos mayoría. tenemos una fe absoluta en el pueblo. Los diez años de guerra nos han dado un enorme prestigio entre las masas. $Y$ éstas saben que nosotros sí seríamos capaces de hacer un cambio real. . . No nos queda la más mínima duda que, bajo las condiciones planteadas por nosotros. . logramos ganar las elecciones porque somos, de hecho, la fuerza mayoritaria en el país... Nosotros no dudamos que si se realiza una contienda limpia, las masas buscarán votar por quien represente un cambio a esta crítica situación y el ideal de cambio no puede representarlo ARENA sino, indiscutiblemente, las fuerzas agrupadas alrededor de la izquierda democráticorevolucionaria." ${ }^{136}$

La ruptura que se operó en esta situación obedeció a que el 
candidato de la CD era el Dr. Ungo, quien era a su vez el presidente del FDR, entonces la decisión del FMLN de sabotear las elecciones se interpretó como algo que indicaba que no estaban de acuerdo con la decisión de que se participara en las elecciones.

La situación se volvió más clara luego de la decisión del FMLN de lanzar la ofensiva de noviembre de 1989, que no contó con el aval de la $C D$. Pero cuando definitivamente la separación se dio fue en el inicio del proceso de negociación entre el FMLN y el Gobierno, que tuvo a estos dos actores únicamente; en este momento desapareció realmente el FDR y de allí el pacto de alianza con el FMLN. A partir de ese momento el actor de izquierda en la negociación fue el FMLN, el FDR ya había sido desplazado completamente por la CD y ésta únicamente fue consultada en algunas ocasiones, pero lo que privó fue la posición del FMLN, prueba de ello es que los firmantes de los Acuerdos de Paz fueron el Gobierno y el FMLN. La situación entre la CD y el FMLN no puede decirse que fue tirante, todo lo contrario, fueron relaciones cordiales, solo que con menor nivel de compromiso que cuando existía la alianza FDR-FMLN .

Por si fuera poco, en 1991, para las elecciones de asamblea y alcaldes, de nueva cuenta el FMLN volvió a mostrar una total indefinición sobre el tratamiento de las elecciones, en esta ocasión llevaron algunos candidatos a través de la $C D$, algunos de ellos resultaron electos, si bien en esta ocasión no fueron declaradas objetivos militares, si dejaron entrever una total indefinición y desatino, por ejemplo, uno de los miembros de su Comandancia General declaró, más o menos los siguiente: "Le pedimos a nuestras bases que no vayan a votar. Pero si se presentan a la mesa de votación anulen el voto. Pero si tienen el deseo de votar háganlo por la Convergencia Democrática", queda esta frase para los anales de historia política salvadoreña.

Los movimientos han continuado en la izquierda, en 1992 el MNR decide apartarse de la CD y su puesto lo ocupa la UDN, partido que unos meses antes de integrarse a la CD se había separado de sus estrechos vasos comunicantes con el PCS y se había decidido por tener personalidad propia. En 1993 los tres partidos conformantes de la CD (MPSC, PSD y UDN) deciden fundirse en un sólo partido, bajo el nombre de Convergencia Democrática. 
El FMLN, como producto de los acuerdos de paz, desapareció como estructura militar y quedó únicamente como fuerza política, en 1992 es inscrito como partido político, con cinco tendencias a su interior, lo cual lo convierte en un partido frentista y no como a un todo orgánico. $Y$ sus problemas y diferencias internas han continuado. Incluso la ERP experimenta una nueva escisión, en 1993 una fracción decide separarse y se denominan Tendencia Democrática (TD), que se dice constituye la sexta tendencia en el FMLN.

La participación que la izquierda tuvo en las elecciones de 1994 ya la hemos analizado y llegamos a la conclusión que privó más la división que la unidad en dicho evento, situación en la que privó más el interés del FMLN, a ellos es que se les debe atribuir el mayor nivel de responsabilidad a este respecto.

\section{Mas allá de los simples resultados electorales}

$\mathrm{F}^{\mathrm{n}}$ todo proceso electoral, los resultados son importantes, éstos Lya se mencionaron al inicio de este trabajo, es importante destacar que ARENA se constituye, de nueva cuenta, como el partido que logró un gane indiscutible en los tres tipos de elecciones que se llevaron a cabo. El FMLN logró el segundo lugar, seguido muy de cerca por el PDC, esto en cuando a votos obtenidos, pero en lo que respecta a resultados electorales concretos, el PDC aventaja al FMLN: los 29 municipios ganados por el PDC contra 13 ganados por el FMLN o de los 15 alcanzados en coalición, son una muestra clara; asimismo el PDC inscribió planillas en $256 \mathrm{mu}-$ nicipios, mientras que el FMLN lo hizo en 241, es decir que la organización del PDC tiene un carácter más nacional que el Frente, incluso el PCN inscribió más planillas, 251 en concreto (cuadro $\mathrm{N}^{\circ} 7$ ). Por otra parte, los 18 diputados del PDC están en una mejor posición que los 21 del FMLN, si descontamos que el diputado $\mathrm{N}^{\circ}$ 21 del Frente en realidad debería ser de la $C D$, pero como no lograron inscribir sus candidatos a la Plancha Nacional, debido a problemas intemos, nos queda que en realidad el Frente, de acuerdo con la votación, debería de contar con 20 diputados, apenas dos más que el PDC. Afirmamos que los 18 del PDC se encuentran en mejor posición por varias razones: la primera de ellas estriba en que resulta más fácil para el PDC lograr un entendi- 
miento-concerta-cesión de acuerdo con el caló político en México-parlamentario con ARENA.

El PDC en varias ocasiones ha logrado un entendimiento en la Asamblea con ARENA, ante todo cuando se requiere del voto calificado para votaciones, que implica un mínimo de 56 votos, los cuales pueden ser logrados por la suma de los diputados de ARENA y del PDC. Este tipo de votación se requiere para la ratificación de las reformas constitucionales (caso del artículo 110, donde se elimina el monopolio estatal en los servicios de teléfono y correos, que se dio en la legislatura pasada), o bien en las reformas que se aprobaron en abril último y que deben ser ratificadas por la actual asamblea. También está el caso de la ratificación de los préstamos externos. Para el FMLN debería ser más dificil lograr un entendimiento en estos ámbitos, por lo tanto de llegar a un arreglo con ARENA. ${ }^{37}$ En segundo término, la bancada del PDC cuenta con mayor experiencia parlamentaria, muchos de sus 18 diputados ya lo han sido en otras ocasiones, mientras que en la del FMLN sólo uno cuenta con dicha experiencia, Dagoberto Gutiérrez que fue diputado en los 70 con la UNO; esta situación poco a poco irá mejorándose para el Frente, conforme vayan ganando experiencia parlamentaria.

Por otra parte, la posición del FMLN como segunda fuerza electoral es muy endeble, así tenemos, que al ser un partido con cinco tendencias y que Shafick Handal dijera que "El FMLN es un partido de partidos, no de tendencias, esto en ocasión de la convención de dicho partido,celebrada en agosto de 1994, de igual manera se ha referido el ERP (anexo $\mathrm{N}^{\circ}$ 2), (al decir de la UCA en uno de sus comentarios, afirma que) por oscura que sea la definición de Handal, ella expresa de alguna forma la profunda y difusa crisis por la que pasan las élites de la mayoría de los institutos políticos $^{\prime 38}$. Si a esto le agregamos el hecho de que sus 21 diputados se encuentran distribuidos así: siete de las FPL, cinco de la ERP, cuatro del PCS, tres de la RN y dos del PRTC como se desprende, el PDC más que duplica los diputados de las FPL y supera a la suma de las tres tendencias que tienen mayor número de diputados. Al analizar los resultados de la votación para diputados por departamento, que es donde son directamente comparables el FMLN y el PDC ya que participaron sin coaligarse, lo 
primero que resalta es que el FMLN supera al PDC en cinco departamentos, en dos de ellos tienen resultados muy similares (Santa Ana y San Vicente); la principal cancha del Frente lo constituye San Salvador, donde logró casi triplicar al PDC, y por diferencia en nueve departamentos, el Frente queda en inferioridad. (cuadro $\mathrm{N}^{\circ} 4$ y 5 )

Con la división del FMLN, que se hizo pública y manifiesta con el triste espectáculo que brindaron el $1^{\circ}$ de mayo, en ocasión de la toma de posesión de la nueva Asamblea, situación que ha continuado, con las amenazas de expulsión de la dirigencia de la ERP y RN, con las sanciones a Villalobos y Sancho, además de las declaraciones vertidas por éstos dos con ocasión de los sucesos de fines de septiembre en la toma de rehenes en el recinto legislativo de varios diputados, acción que realizaran desmovilizados de la Fuerza Armada, manifestaron que dicha acción era producto de un plan desestabilizador del sistema impulsado por las FPL ${ }^{39}$. Estas negaron toda vinculación con el hecho. A partir de este momento la situación al interior del Frente se volvió más candente, el cinco de octubre, el PCS le planteó a Villalobos y a Sancho a que se separaran del FMLN y a que ejecuten un nuevo proyecto político, "deben consumar su separación ya que sus posiciones se apartan de los límites del debate politicoideológico y entran al terreno de las calumnias y las artimañas ${ }^{\prime 40}$, éste debe ser el que ellos quieran, es decir socialdemócratas como se han declarado la ERP y RN.

Ante esta ola de acusaciones y contraacusaciones, de todas las organizaciones que conforman al FMLN, han surgido propuestas diversas, como la de Ana Guadalupe Martinez (ERP y vicepresidenta de la Asamblea) que indicó lo siguiente: "El deterioro ha llegado a tanto en el FMLN que lo mejor sería no seguir manchándolo, ya que es un sujeto histórico que cobijó en la guerra a mucha gente y propició cambios importantes en el pais.. . (dijo que) el FMLN pudo haber servido para la guerra, pero en la paz ya no es necesario; cada uno debe decidir lo que quiera y organizarse como quiera." ${ }^{\prime 1}$

La disputa se ve en los siguientes términos: "su causa es la disputa entre marxistas y socialdemócratas, situación que afecta la credibilidad del FMLN, por el grave golpe que se le está dando en los últimos días. Las desaveniencias políticas del FMLN son, 
para la mayoría de los analistas, el principio del fin de la alianza. Así las cosas, la pelea es hoy por quien se queda con las siglas FMLN; los socialdemócratas piden que se disuelva y los marxistas que éstos se vayan del partido." ${ }^{\prime \prime 2}$

Pero la situación no para allí, sino que hay signos verdaderamente preocupantes en el comportamiento de la izquierda en su conjunto, con especial énfasis en lo que sucede al interior del FMLN. Para nuestro entender, la disputa no es sobre sí los sucesos del $1^{\circ}$ de mayo, le dan la razón o no a unos u otros, a este respecto se considera que lo más adecuado es estar representado ante la Junta Directiva de la Asamblea; podrán haber discrepancias a este respecto ${ }^{43}$, es más, la decisión de integrarse estaba decidida a nivel de las cinco organizaciones (partidos según Shafick Handal) del FMLN, en una votación de 4 a 1, con la abstención del PCS, pero la disputa surgió en la conformación de la Junta Directiva respecto de si el presidente debía tener voto cualificado o no. A este respecto, privó la posición de 3 a 2 respecto de rechazar dicho voto cualificado. Es por esta razón que el día $1^{\circ}$ de mayo, los 21 diputados del FMLN llegaron sin una posición unificada y es cuando ardió Troya. En este caso, 7 diputados de la ERP y RN se abrogaron un derecho parlamentario que les confiere el Reglamento Interno de la Asamblea y propusieron dos nombres para integrar la Junta Directiva, resultando electos Ana Guadalupe Martínez como Vicepresidenta y Eduardo Sancho como Secretario. A los restantes 14 diputados del FMLN no les quedó más derecho que el 'grito del cuche' (ver nota $N^{\circ} 37$ ). Según informaciones obtenidas en octubre de este año, aunque sin confirmar, el PCS, PRTC y FPL han mostrado interés en ocupar una silla en la Junta Directiva.

Como ya lo dijéramos, lo preocupante no es haber ocupado los puestos de la Junta Directiva de parte de la ERP y RN (de ahora en adelante los denominaremos como F2), sino que son las actuaciones posteriores que han tenido como sub-fracción parlamentaria, por ejemplo se menciona lo siguiente: "Al llegar a la vida política, luego de la firma de los Acuerdos de Chapultepec, se hizo notorio el oportunismo del grupo lidereado por Joaquín Villalobos que han llegado a entrar en un claro arreglo con el oficialismo no sólo en la Asamblea Legislativa sino también dentro de un plan de atomización de la oposición que ARENA ha 
planteado para poder perpetuarse en el poder. ${ }^{\prime 44}$ De ser cierta esta aseveración, aunada al hecho de que incluso la acusación que hiciera Villalobos a las FPL, de que habían promovido la ocupación de la Asamblea a finales de septiembre desde la sede del partido ARENA, es algo que sí merece una explicación, porque constituye, a nuestro entender, un desentendimiento total a la memoria de tantos mártires que ofrendaron su vida por conseguir una sociedad mejor, donde queda la denuncia permanente de Monseñor Romero, la crítica de los Jesuitas, los compañeros del FDR, el sacrificio de casi 80 mil compatriotas, a lo que se suman los desaparecidos, los torturados, los exiliados, etc.

Pero igualmente preocupante es lo que sucede en el bloque compuesto por el PCS, el PRTC y FPL, (de ahora en adelante lo denominaremos como F3), ya que según diversos artículos de análisis que se han realizado, los ubican como que "han evadido plantearse con seriedad las transformaciones que exige la nueva coyuntura y su entorno internacional" ${ }^{\prime 5}$ o bien lo planteado de esta manera: "Pero esta división no se limita a un bloque ERP RN y a otro FPL-PCS-PRTC, por el contrario, el segundo bloque presenciará más temprano que tarde la separación de las FPL, quedando un sector de extrema izquierda que probablemente se aglutinará en el histórico Partido Comunista Salvadoreño, haciendo desaparecer al PRTC. ${ }^{46}$, también está el siguiente planteamiento "Igualmente legítima es la opción del F3 de mantenerse adscritos o no haber renunciado explícitamente al marxismo-leninismo. Pero sería un grave error que estas organizaciones no se hicieran cargo tanto de la crisis teórica e histórica del marxismo-leninismo como de la necesidad de trabajar por un proyecto de socialismo factible." ${ }^{47} \mathrm{Se}$ podría continuar con este tipo de argumentos, pero no resultan al caso, sino que lo importante es que evidencian que la discusión se encuentra ya en el nivel de lo público.

En realidad lo que se aprecia es una seria crisis en la izquierda salvadoreña, que no es la primera ni la última, tampoco es la única izquierda en el mundo que presenta grave crisis, así como tampoco es el único bloque político salvadoreño que se encuentra en crisis, al interior del PDC hay fraccionamientos profundos; en la derecha, en ARENA se dice que existen tres tendencias, la tecnocrática lidereada por el grupo Cristiani, la burocrática cerca- 
na a Calderón Sol y los escuadroneros que son los fundadores, que permanecen en constante pugna por controlar al partido y las decisiones gubernamentales; por otra parte, el aparecimiento del Partido Libertad y Democracia (PLYD) y su cruzada contra la corrupción le han generado un duro golpe a ARENA, tal vez el de mayores consecuencias en lo que va de la presente década, dada la veracidad de los casos de corrupción en que se han visto involucrados varios de los miembros de su gabinete, así como de prominentes figuras de su dirección nacional. Tal pareciera que para que la cuña apriete debe ser del mismo palo.

Pero si por todos lados se evidencia la crisis, esto no debe servir de consuelo para la izquierda salvadoreña, lejos de ello, debe posibilitarle el proyectarse con visión de futuro y salir fortalecida de esta situación, en este ámbito se debe considerar al F3, al F2, a la Convergencia, al MNR como fuerzas.políticas existentes en estos momentos; al igual los sectores laborales deben redefinir su papel, no pueden continuar bajo el tutelaje estricto de los partidos políticos y éstos deben tener claro que el movimiento laboral y social debe tener sus propias aspiraciones, su propia personalidad y por que no decirlo, su propia autonomía, aunque parezca redundante, para el caso de la historia de este movimiento no lo es en estos momentos.

Ante la disparidad de posiciones y con la evidencia clara de serias contradicciones al interior de la izquierda, y en concreto del FMLN, que lejos de aparecer como un partido monolítico y bien cimentado, más bien hay que analizarlo como dividido, a este respecto, se puede decir que el Frente es un mosaico ya que desde los 80 si se le ve desde lejos, se apreciaba como un cuadro íntegro, pero al acercársele, aparecía como un cuadro formado por mosaicos, es decir compuesto por diversos trozos, separados entre sí, diferenciados entre sí, pero que asemejaban un todo único, el Frente después de las elecciones continúa presentándose como un mosaico, sólo que desarticulado y con dificultad de poder presentarse de nuevo unificado. Lo mismo se puede decir de la izquierda en su conjunto, donde las nueve tendencias que se presentan no logran articular un determinado proyecto único, sino que continúa padeciendo del grave problema de las izquierdas en el mundo, que es el del vanguardismo y hegemonismo, que vuelve dificulto- 
so un proceso de reunificación (grave enfermedad infantil).

Dentro de los análisis de la UCA, este fenómeno lo ve en el siguiente sentido: "uno de los rasgos característicos de la izquierda salvadoreña ha sido su capacidad para dividirse y multiplicarse... Desde su constitución - y ya integrados al FMLN- cada uno de estos núcleos tuvo estrategias, planteamientos e intereses distintos... en su momento cada uno de ellos quiso imponer a los demás su propio proyecto... Durante la guerra, nos acostumbramos a ver a una única izquierda. El compromiso por alcanzar una solución negociada a la guerra y la firma de los Acuerdos de Paz nos hicieron pensar en una izquierda creativa y con enorme potencial para democratizar la sociedad salvadoreha... Finalizada la guerra, en un nuevo marco donde las armas a utilizar son el debate político e ideológico y donde lo que se busca es la concertación y el consenso entre actores plurales, la herencia del pasado de intolerencia y fanatismo que caracterizó a la izquierda reaparece como un fantasma con el que ésta -quizás por necesidades de identidad - tiene que convivir." ${ }^{\prime 4}$

$\mathrm{Si}$ resumimos lo que dejaron las elecciones de marzo, ello se puede decir tocando los siguientes puntos:

a) Una izquierda dividida, más de lo que ya estaba, con el agravante de que se encuentra enfrascada en una discusión esteril, ¿Quienes son socialdemócratas y quiénes son marxistasleninistas? En todo caso la discusión es sobre 'viñetas' y no sobre proyecto a futuro, en otras palabras, están colocando la carreta adelante de los bueyes, ya que en todo caso no se encuentran discutiendo los grandes problemas nacionales: democratización, participación popular, la globalización económica, la integración regional, la devastación del medio ambiente, la pobreza, la reformas políticas, etc.. Es tan grande la agenda que resulta inoficioso pretender indicar todos los elementos deben estar incluidos en la agenda de discusión sobre lo que debe ser el futuro de la sociedad salvadoreña, después de los Acuerdos, pero en el espiritu de la discusión actual ello no aparece. La discusión es sobre quién se queda con el nombre del FMLN (F3 ó F2) o si éste debe desaparecer. "El Frente ya no da, es triste pero es la verdad." Fue la expresión que utilizó un militante de la ex-guerrilla en ocasión de la convención del FMLN que rea- 
lizara el 30 de agosto de 1994. "Para los dirigentes del PCS, el dilema es de que se trata de una premeditada acción del F2, encaminada a afectar y debilitar políticamente al FMLN a toda costa para abrir espacio a su propio proyecto político. Según un alto dirigente de las FPL, el propósito de aquellas dos organizaciones enfrentadas en la práctica al resto del Frente, tendría como una de sus razones la gran envidia -que no pueden ocultar- contra las FPL" ${ }^{\prime 9}$. Pero y en toda esta discusión; ¿cómo se encuentra el pueblo? ¡muy bien gracias!

b) La preeminencia del partido ARENA, que en los cuatro procesos electorales celebrados desde 1988 se ha constituido en la principal fuerza politica del país y lo que es más grave, hay una consolidación del pensamiento derechista. El bloque de partidos de derecha (cuadro $\mathrm{N}^{\circ} 2$ y gráfico $\mathrm{N}^{\circ} 2$ ) se constituye como el hegemónico, logra más del $50 \%$ de los votos válidos.

En 82 municipios alcanzó más del $50 \%$ de los votos. En otras palabras, pareciera que tiene preeminencia ideológica. Sobre esta situación, en varias escritos y conferencias se ha dicho, que se está cerca de un proceso de "Priización' de la estructura política salvadoreña (es decir siguiendo el modelo del PRI en México), y que ARENA, vendría a ocupar un papel similar al del PRI. Sobre esta apreciación estamos en total desacuerdo, no porque ARENA no pueda pasar varios años gobernando, sino por el hecho de que la ubicación de ARENA en el espectro político, está lejos de la posición del PRI.

El PRI, en primer lugar tiene un origen popular, es el producto de una revolución social. En su historia ha pasado desde el movimiento socializante impulsado por Lázaro Cárdenas en la década del 30; ha sido populista como en los años 70 y ha sido neoliberal con Salinas de Gortari; mientras que ARENA no puede tener este tipo de movimientos, pero ni tan siquiera en el campo de lo táctico, ya no digamos en políticas de Estado, en primer lugar se encuentra en el extremo del expectro político, situación que le dificulta, sino que le impide el hacer reacomodos.

c) Al observar la evolución electoral por bloques políticos (cuadro $\mathrm{N}^{\circ} 2$ y gráfico $\mathrm{N}^{\circ} 2$ ), se aprecia que en cada bloque existe un partido fuerte: en la derecha es ARENA, en el centro es el PDC 
y en la izquierda es el FMLN, las opciones de izquierda democrática muy poca fuerza han tenido. Por otra parte, hay una situación que en las elecciones de 1994 quedó muy clara y es el hecho de que la suma de porcentajes de votos del centro e izquierda, tiene una especie de 'suma cero', en el sentido de que lo que pierde el centro lo ha ganado la izquierda. En 1988, cuando no participó la izquierda, el centro alcanzó el $37.4 \%$ de los votos. En 1989, cuando por primera vez participa la Convergencia Democrática, el centro logró $36.8 \%$ y la izquierda $3.8 \%$, la suma de los dos fue de $40.6 \%$. Para 1991, el centro logró $28.6 \%$ y la izquierda $14.8 \%, 1$ a suma de los dos alcanzó $43.4 \%$. En marzo de este año, en las elecciones presidenciales, el centro logró $19.7 \%$ y la izquierda con $25.0 \%$ (aqui ya participó el FMLN), la suma de los dos fue de $44.7 \%$. De esta evidencia, se puede deducir que con este tipo de resultado, lo que se está es facilitando las cosas a ARENA, quien no avisora todavía una real disputa de su hegemonía, ya que no se percibe que el sistema político esté actuando en dicho camino, ya que al estarse dando la disputa entre el centro y la izquierda, ARENA queda con grandes libertades. Por lo tanto se puede indicar que para destronar a ARENA, sólo puede lograrse con la conjunción de esfuerzos del centro e izquierda. Lo cual coloca a la disputa que se está dando en la izquierda, en un campo negativo, ya que le facilita aún más las cosas a ARENA. Igual referencia se puede decir respecto del pleito o disputa que se está dando la interior del PDC, entre las tendencias chavistas y abrahamcistas, que no presagian nada positivo para fortalecer al centro, pero si para facilitar la hegemonía de ARENA.

Como resultado de estas disputas internas e intestinas, en el centro e izquierda, la propuesta de La Trenza no pudo concretarse. En caso de haberse logrado dicho entendimiento, los resultados electorales fueran cualitativamente diferentes, por ejemplo, la Asamblea estaría equilibrada, con 42 diputados que lograría La Trenza más el del MU, frente al otro bloque formado por ARENA y el PCN que hubiese llegado también a 42 diputados. En el campo de las alcaldías, las 15 que logró la izquierda y las 29 que ganó el PDC suman 43; en caso que las alcaldías hubiesen llevado candidatos comunes, el PDC y la izquier- 
da, el total de alcaldías ganadas hubiese llegado a 114 (cuadro $\mathrm{N}^{\circ}$ 9), es decir más que se hubiesen duplicado. Nadie puede decir que esto no representa un salto cualitativo de claras ganacias políticas tanto para el PDC como para el FMLN, ya no digamos para fortalecer el proceso de democratización iniciado a partir de los Acuerdos de Paz.

d) El sistema de partidos es cruel en sus determinaciones, y una de sus más claras lecciones es que no acepta escisiones de partidos, ya que todas las que han ocurrido desde 1982, al menos, han desaparecido. De acuerdo con el cuadro $\mathrm{N}^{\circ} 2$, vemos que las diversas escisiones del PCN, PAISA, MERECEN, POP, a lo largo de unas dos votaciones han desaparecido. Por el lado de PDC, lo mismo ha sucedido con el MAC. Las esciciones que ha experimentado ARENA, como el caso de LIBERACION y de la posterior coalición que hiciera con el PPS para formar la UP, también desapareció. En el lado de la izquierda, el MNR al separarse de la Convergencia, se encuentra en peligro de desaparecer, la UDN que se separó del PCS, no le quedó más remedio que arrimarse al MPSC en la conformación de la Convergencia como partido; de haber continuado sola, la UDN irremediablemente hubiese desaparecido en 1994.

De esta especie de determinismo a que se encuentran sometidos los partidos políticos salvadoreños, nos preguntamos si la división planteada en estos momentos en el FMLN, conducirá a los mismos resultados. Habría que esperar, por lo menos unos tres procesos electorales más, es decir hasta el año 2000 para ver si se cumple este determinismo o ley de hierro que pesa en el sistema de partidos salvadoreño.

e) Las propuestas programáticas de los partidos, principalmente de izquierda encuentran serias limitaciones para poder proponer los lineamientos tradicionales de estas tendencias; esta situación se debe en principal medida al predominio del modelo neoliberal, que ha cortado las iniciativas a la izquierda. La izquierda en general, y la salvadoreña no es la excepción, se encuentra atrapada en sus diseños estratégicos, debe aceptar que el tiempo de las revoluciones armadas victoriosas ha pasado, que las posibilidades de implementar un modelo socialista or- 
todoxo es cosa del pasado, que la teoría marxista-leninista fue enterrada por la realidad histórica, que la época de caudillos ha sido superada, etc. Ante esta situación no les queda otra disyuntiva como la planteada por Bourdieu: "La política es un monopolio de aquellos interesados en la política ... pero no son totalmente autónomos en su producción, sino que se encuentran condicionados por el medio político que los rodea, es decir por el mercado político del sistema imperante, en otras palabras toman en cuenta la competencia. Por esta razón, los partidos se ven impulsados por dos tendencias contradictorias: a) aquella que los lleva a indicar que son diferentes de los demás $y, b)$ La que los empuja a ampliar su base anulando las diferencias." ${ }^{50}$ La segunda es la que predomina en estos momentos, incluso la Plataforma Electoral de la Coalición CD-FMLN-MNR contiene propuestas neoliberales "...La noción misma de una nueva sociedad pareció esfumarse en los planteamientos de la Coalición y ceder a la lógica discursiva impuesta por ARENA... el programa de cambios estructurales que dieron contenido al ideario de la izquierda a lo largo del conflicto se ha diluido en una plataforma programática más cercana en su lógica a la propia propuesta de ARENA que a las exigencias de reconstituir las bases económicas de la sociedad salvadoreña en función de los intereses de las mayorías populares."

f) El sistema de partidos se encuentra en real crisis de identidad, no representa a una buena parte del electorado potencial, el alto índice de abstención real que se manifestó en marzo, en las 'elecciones del siglo' indica que una buena parte de salvadoreños no cree en los actuales partidos. La cifra exacta del padrón electoral se desconoce, pero se sabe que cuenta con un aproximado de 2.7 millones, pero es un padrón inflado, ya que no se le han descontado los muertos (en marzo aparecieron Duarte, Ungo, D'Abuisson, etc), también contiene gran cantidad de personas que se encuentran residiendo en el extranjero; al descontarle todas estas 'anormalidades', se cree que una cifra real sobre las personas 'aptas' para votar de acuerdo con el padrón es de unas 2.2 millones. Pero también no contiene a una buena cantidad de personas que teniendo su carnet electoral no aparecen en los listados de las votaciones. En resumidas 
cuentas, en el padrón se encuentran muchos que no deberían estar, y muchos que sí deberían estar no aparecen.

En la primera vuelta electoral para presidente los votos válidos fueron 1'326,836 (60.3\%), los que emitieron voto fueron 1'431,035 (65.0\%), de allí que el abstencionismo pueda calcularse en $40 \%$. Para la segunda vuelta el abstencionismo fue de $45.6 \%$. Esto quiere decir que el discurso de campaña de los partidos políticos no le llegó a casi la mitad de los aptos para votar con que cuenta el padrón electoral, ésto que era para las así consideradas 'elecciones del siglo'. Ante este nivel tan elevado de abstencionismo, se carece de la debida representatividad, no solo del partido en el gobierno, sino el sistema de partidos en su conjunto. Situación que se ve agravada por el hecho de que los partidos, merced de sus disputas y divisiones post-electorales, lo que hacen es acentuar la inconformidad del electorado, quien además se siente defraudado por el hecho de que votó por una determinada opción y una vez electos, las disputas hacen que se frustren aun más de lo que ya estaban. Nos preguntamos cómo se sentiran muchos de los votantes del FMLN y del PDC ante las disputas que estos dos partidos han presentado después de las elecciones o bien cómo se sentirán de defraudados los que lo hicieron por ARENA, si en el gabinete hay personas identificadas claramente como corruptas, o que en el gobierno de Cristiani hasta el mismo presidente ha sido señalado como corrupto, además de otras personas que formaron su gabinete.

g) La sociedad civil es tremendamente débil, lo que conduce a una 'Democracia Delegativa', ya que con la tremenda desigualdad que caracteriza a la sociedad salvadoreña, que contiene elementos de 'apartheid social', con excesiva debilidad del Estado -que contiene grandes áreas de exclusión, es decir donde no llega su incidencia, como son: el narcotráfico, el contrabando, la corrupción, la pobreza, la economía informal, el lavado de dólares, la evasión de impuestos, la delincuencia, etc.-. Por Democracia Delegativa se entiende "que es aquella democracia donde los individuos son desiguales, dependientes e incapaces de hacerse representar, además, los individuos no encuentran cómo hacer para reclamarle al Estado, por lo tanto éste se con- 
sidera con más poderes... Ante ello, lo frecuente es que se haga acompañar de figuras como las del liderazgo personal, elecciones plebiscitarias, voto clientelístico, etc." 52 Para citar algunos indicadores al respecto, la pobreza crítica alcanza a $45 \%$ de las familias; el $\mathbf{8 5 \%}$ de las familias carece de un ingreso que le sea suficiente para cubrir los requerimientos de costo de la canasta básica ampliada, la evasión de impuestos es del $50 \%$ (en el IVA llega a 57\%), el sector informal agrupa a por lo menos 500 mil personas; la corrupción está presente en altas esferas del gobierno, Kirio Waldo Salgado ha implicado a las siguientes personalidades públicas: Ministro de Hacienda, Ministro de Agricultura, Expresidente Cristiani, Exministro de Defensa, Exviceministro de Defensa, Expresidente de CEL, Exministra de Planificación, etc., y la sociedad civil se ha quedado callada ante estos hechos, cuando en otros países como en Brasil, Venezuela han caído presidentes por este tipo de delitos; los niveles que ha adquirido la delincuencia son desproporcionados, pareciera que los muertos por la guerra ahora son ocasionados por 'asesinos que roban' es decir de aquellos que primero matan y después ven qué es lo que lleva encima la víctima; la proliferación del problema social de 'las Maras', el lavado de dólares es escandaloso, se dice que en San Miguel se ha constituido un paraíso para este delito; la incapacidad para controlar el narcotráfico es notoria, llegando al colmo de soltar a aquellos que han sido atrapados con 'la coca en las manos' como el caso de la avioneta que fue capturada en San Diego, La Libertad, o bien el caso de la inmensa cantidad de cocaína que se encontró en las bodegas de la Antigua Calle a San Antonio Abad o que el reconocido narco mexicano, el Chapo Guzmán, visitaba frecuentemente El Salvador (tiene una foto tomada en la Plaza del Trovador), etc., son todos claros indicios de la debilidad del actual Estado salvadoreño, que incluso se debilita cada día más como producto del adelgazamiento a que se ve sometido por las politicas neoliberales implementadas por los gobiernos de ARENA.

El crecimiento de las áreas de exclusión del Estado, principalmente en las referidas al crecimiento de los problemas sociales (pobreza, hambre, etc.), conduce, de manera peligrosa, a un 
proceso de ANOMIA social donde no existen normas claras ni interlocutores concretos, en donde la posibilidad de que el lumpen desorganizado y sin guía se revele en una protesta social sin control, en otras palabras, que se puedan repetir los sucesos de Buenos Aires, Río de Janeiro, Los Angeles, etc.

h) A esta debilidad de la sociedad civil y del sistema de partidos, se le suma la debilidad manifiesta de la oposición política, que no encuentra el camino de lo que debe hacer. Las disputas al interior de cada uno de los segmentos de la oposición, Frente y PDC principalmente, están debilitando las posibilidades y potencialidades. Por ejemplo, para Rubén Zamora "Una lucha intestina muy prolongada al interior de un partido impide que la oposición cumpla con su papel. Así tenemos, el PDC y el FMLN se pasan el $70 \%$ del tiempo en su pleito interno", para Roberto Viera (dirigente del PDC) se pronuncia porque "los problemas al interior -crisis interna de liderazgo- del PDC interfieren con el efectivo ejercicio de la oposición." ${ }^{153}$ Esta situación le permite a ARENA realizar su función de gobernar sin mayores presiones, máxime cuando por ejemplo, diputados del FMLN, como el caso de Eduardo Sancho (F2) manifiesta su oposición a que se conforme una comisión especial legislativa para que analice los casos de evidente corrupción denunciados por Kirio Waldo Salgado, negando así la posibilidad de ejercerle un juicio político a ARENA. Este tipo de actuación más parece ser una clara concerta-cesión, negativa incluso para un mejor desempeño de la función de gobernar, reforzada esta situación con el hecho de que uno de las funciones básicas del órgano legislativo, al menos en lo que se refiere a la oposición, es la de fiscalizar al gobiemo.

i) A lo anterior se suma la debilidad propia del FMLN, sobre la que ya se ha dicho bastante, pero falta mencionar algo que es importante. En varias ocasiones miembros empresariales, que estuvieron opuestos al proceso de negociación con el Frente, han manifestado, a casi tres años después de firmada la paz, que tenían una percepción equivocada sobre el potencial real del FMLN y que éste les ha salido 'un tigre de papel'. Incluso algunos de ellos han llegado a indicar que lo mejor hubiese sido negociar con anterioridad, tal vez en tiempos de Duarte. 
Por otra parte, indicar que dentro de la debilidad manifiesta del FMLN se encuentra el hecho de que en la negociación lo que consiguieron fueron aspectos que la misma derecha estaba dispuesta a conceder, tal como fue el caso de las tierras y de los militares. Pero en los aspectos económicos y sociales han cedido muy poco, tal como se manifiesta en los magros resultados, en beneficio de los sectores más necesitados, obtenidos en el Foro de Concertación Económico y Social.

Sobre este punto se considera oportuno hacer el siguiente comentario: los resultados y logros obtenidos a través del proceso de negociación, de cara a los intereses del FMLN, resultan ser inferiores a las posibilidades que ofrecía en su época (1979) la Proclama de la Fuerza Armada y la instauración de la Primera Junta de Gobierno con la participación del Foro Popular, a la que no pocas organizaciones atacaron desde su primer momento, entre ellas: el ERP y las FPL. Aunque se debe aclarar que el contexto en que se dio el golpe en 1979 eran de efervescencia revolucionaria, misma que se evidenciaba en una de las consignas de la época que decía ¡Si Nicaragua venció, El Salvador vencerá!; por tanto, para las organizaciones políticomilitares el involucrarse en el espacio que abrió el golpe era renunciar, lo cual en esos momentos era una clara traición, a las posibilidades de repetir la historia sucedida en Nicaragua.

j) Hay un elemento de suma importancia que ha dejado el proceso electoral y es el referido à la evidente pérdida de protagonismo del sector militar, al menos en la política partidista, la preeminencia que mantuvieron desde 1 931, comienza a disminuir con el golpe de estado de 1979, aunque esto parezca una paradoja, ya que durante la guerra, su presencia se incrementó. La explicación a esta paradoja se da de la siguiente manera: el gelpe de 1979 impulsado por sectores militares, con una clara orientación reformista antioligárquica, le indicó al gran capital que había terminado el tiempo en el cual otros les representaban y defendían sus intereses, por esta razón es que se avocan a la conformación de su propio partido, ARENA, donde las figuras políticas pertenecen a los sectores del gran capital.

En los inicios de ARENA, la presencia de militares se hizo presente, hay que tomar en cuenta que su fundador, R. D'Aubuisson, 
era militar, pero la cúpula partidista estuvo dominada por miembros del gran capital. Durante el período de guerra, el capital utilizó a los militares para la defensa de sus intereses, pero no les permitieron preeminencia en el área politica. LLegada la paz, el gran capital ya no ve con los mismos intereses de protección a los militares, es más fue uno de los sectores que realmente fueron negociados para llegar a los acuerdos de paz. Para las elecciones de 1994, por primera vez en las listas de ARENA no aparecen militares como candidatos a diputados. Este reacomodo que se da en la derecha indica que los militares ya no les ofrecen garantías como en el pasado, ya no hay seguridad nacional entendida como la lucha anticomunista; se terminó la guerra fría, por tanto para ARENA, los militares o se les subordinan plenamente, o bien éstos tienen que verse en la necesidad de crear su propio espacio político, pero en todo caso pierden las preeminencias de que gozaron en el pasado. Estamos en presencia pués, de una disminución de la preeminencia politica de los militares, que ni incluso recurriendo al PCN lograron algún tipo de Incidencia política partidaria.

\section{¿Qué hacer?}

T a crisis general del sistema de partidos, de la oposición y de la - izquierda, que se vive en estos momentos no puede continuar indefinidamente, se debe hacer un alto e iniciar un proceso de recomposición para poder atender la grave problemática socio-económica que afecta a la sociedad.

El sistema de partidos debe reorientarse a buscar la identificación de las necesidades más sentidas de la población y en este camino tiene necesariamente que pasar a ser representativo y no delegativo, como lo ha sido tradicionalmente. En otras palabras, los partidos deben acercarse a la población, conocerla, tal como lo sugiere Gramsci. (anexo $\mathrm{N}^{\circ} 1$ )

Los partidos políticos, de acuerdo con Salvador Samayoa (54) deben readecuarse a las nuevas condiciones bajo las siguientes premisas:

- "Asumir el arraigo social y la representatividad real como principios fundamentales de legitimidad de su existencia y de actuación... Los partidos deben representar, de manera identifi- 
cable, intereses, aspiraciones, planteamientos o proyectos de sectores significativos de la sociedad.

- Trabajar en un proyecto de nación con viabilidad económica, política, social y cultural a mediano y largo lazo... deben cambiar las prioridades en su agenda y en la inversión de sus recursos. El tema central es el crecimiento sostenible.

- Recuperar el valor social y comunitario directo de la actividad política... Corresponde a los partidos generar planteamientos y proyectos a nivel de gobiernos municipales y de ámbitos sectoriales de la administración pública que devuelvan al ciudadano común algún sentido de utilidad y relevancia de la participación política.

- Conceder relevancia y otorgar vigencia a la dimensión ética de la política... Los partidos deben proclamar con energía la necesidad de actuar con apego a valores y principios fundamentales de ética politica, con énfasis en los que se refieren a la justicia social, la solidaridad humana, la honradez incorruptible, la verdad, la transparencia ante el cuerpo social y la lealtad en la lucha politica dentro y fuera de los partidos.

- Modernizarse a fondo y abrirse al relevo de liderazgos en todos los niveles."

La oposición debe jugar correctamente el papel que le corresponde como tal, siendo críticos donde se debe ser, apoyando iniciativas válidas, denegando lo que sea contrario al bienestar general, proponiendo iniciativas que beneficien a la solución de los problemas sociales y económicos. Para ello requiere ser fuerte, tener claridad en sus propuestas. Se debe recordar que uno de los fundamentos básicos que requiere la democracia es la presencia de una oposición fortalecida.

En lo que respecta a la izquierda, la situación se presenta un tanto difícil, la complejidad de su crisis interna, tal como la hemos evidenciado, requiere de soluciones adecuadas. En estos momentos se conocen los siguientes planteamientos de cómo abordar la situación: el de las FPL que propone que desaparezcan todas las actuales estructuras partidarias que existen y que se forme un sólo partido de izquierda, que sea democrático y moderno. El ERP 
ha propuesto que se renonozcan las diferencias que hay en el FMLN y que éste sea entendido como dentro de una política de alianza y no en la búsqueda de una pretendida unidad orgánica tal como ha sido desde 1992. Otros planteamientos apuntan a la disolución del FMLN y que cada quién busque su proyecto político dónde más le convenga a sus intereses; también está la posición del PCS que indica que los conformantes del F2 deben retirarse del FMLN, dado que ya no es posible, de acuerdo con su análisis, resolver las diferencias ideológicas y personales que los enfrentan; dentro de esta posición queda implícito que el nombre del FMLN le quedará a los que - se queden-, que en este caso serían los del F3.

Pasos concretos se han dado a este respecto, en mayo último la ERP, la RN y el casi moribundo MNR deciden implusar lo que han denominado 'agrupamiento socialdemócrata', que ya para los sucesos de finales de septiembre, respecto de la toma del recinto legislativo, se definen en los siguientes términos: "este es un problema de causas reales que está siendo manipulado por Kirio Waldo Salgado como figura pública de sectores de ultraderecha y grupos antisistema vinculados a las FPL para desestabilizar al gobierno... (este agrupamiento hizo el siguiente llamado) .. . a los grupos de ultraizquierda del FMLN a abandonar sus actitudes antisistema y su poco o nulo interés en fortalecer la institucionalidad del país, deslindarse de las actitudes desestabilizadoras de la extrema derecha (sic) y recordar que los derechos de la ciudadania deben ser reclamados a partir de métodos democráticos." ${ }^{155}$ Como puede apreciarse, resulta hasta indignante el trato que se están dando entre sí los antiguos aliados conformantes del FMLN-FDR. Todo pareciera indicar que el "Agrupamiento Socialdemócrata" se encuentra en un proceso de concerta-cesión con el partido ARENA.

En el caso de la posición del PCS, que propone la firma de un nuevo pacto en el FMLN, parte de la premisa de que la unidad política es ya irrecuperable y que el problema inmediato a resolver es el de los costos de la ruptura, en este camino, se trata de forzar a la ERP y RN a rechazar una oferta de salvación de la unidad del Frente o a aceptarla formalmente y no cumplir los compromisos. 
Para la ERP, parte de que la unidad política del Frente está perdida y que lo conveniente es que desaparezca el FMLN y que cada quien se ubique donde mejor le convenga, a lo sumo podrían estar de acuerdo con que se reconsidere la posibilidad de que el Frente deje de ser un partido, como legalmente se encuentra registrado, y que pase a ser de nuevo una alianza de partidos, donde cada uno de sus componentes tenga espacios de autonomía.

Las FPL, proponen la constitución de un solo partido de izquierda, es la propuesta más elaborada que se conoce. Parte de las consideraciones siguientes "La izquierda se ha convertido en la primera fuerza de oposición, sin embargo, por el momento, carece de la unidad política y del proyecto nacional que le permita fortalecerse como sujeto de las transformaciones estructurales, como alternativa de poder y como el necesario contrapeso de la derecha ( $y$ de su proyecto neoliberal), que contribuya a asegurar la gobernabilidad democrática del país.... La proliferación de tantos partidos fragmentados de izquierda no es una necesidad objetiva de sector alguno de la sociedad y menos aún responde al interés general de la nación... La existencia de todos estos pequeños agrupamientos podría no tener más justificación -aunque no sea esa racionalidad consciente y reconocida- que la de asegurar espacios de protagonismo político y plataformas para dirigentes y pequeños grupos con intereses creados. . . En política la pura sumatoria de cantidades no da siempre como resultado una cantidad mayor. Si se carece de un proyecto político viable y coherente, el resultado de sumar tres más dos [en clara referencia al F3 y F2] podría ser cero en vez de cinco [en referencia al FMLN]; y el resultado de sumar tres más dos más tres [en referencia a la CD] más uno [en referencia al MNR] más uno podría quedarse muy lejos de ser diez. . . (La constitución de este nuevo partido) pasa inevitablemente por la demolición y desaparición de las actuales estructuras partidarias que existen.... [Por último proponen que] Conservar el nombre del FMLN es importante en la medida que con ello logremos reafirmar la esencia democrática, popular y revolucionaria de su proyecto histórico. Si ello no es posible, sería mejor que la gesta heróica protagonizada por el FMLN quede grabada en la historia nacional ... y continuar el proceso creando 
un nuevo instrumento de lucha adecuado al nuevo período histórico." 56

Las FPL también parten de que la modalidad del FMLN como partido único, como unidad política es ya irrecuperable, esto se aclara cuando afirman que "Actualmente se debaten en su seno dos proyectos políticos claramente diferenciados e incompatibles dentro de una estructura partidaria, aunque sí compatibles dentro de una política de alianzas." ${ }^{17}$

Se desconocen los planteamientos de las otras dos organizaciones conformantes del FMLN, (PRTC y RN) así como de la Convergencia y del MNR, referentes a cómo abordar la situación de crisis por la que está atravezando la izquierda salvadoreña.

De nueva cuenta se aprecia que en las discusiones y planteamientos vertidos, se encuentra un vacío en lo referente a programa o proyecto para enfrentar la problemática socio-política y económica que enfrenta en estos momentos la sociedad salvadoreña.

Desde nuestra perspectiva creemos que la izquierda debe tomar esta discusión con seriedad, con visión de futuro, sin pretendidos hegemonismos y vanguardismos. En primer lugar creemos que deben tener la suficiente madurez para aceptar errores y planteamientos críticos, discutir con el criterio de aprender, es decir tener humildad ante todo, en este ámbito resulta altamente positivo iniciar por conocer a El Salvador y su sociedad, tal como lo plantea Gramsci (anexo $\mathrm{N}^{\circ} 1$ ), el entorno regional e internacional, los cambios que implican la revolución tecnológica de la microelectrónica, los nuevos materiales y la biotecnología, nuevos aportes en sociología, en teoría política, etc.

Sobre los planteamientos vertidos por las diferentes organizaciones del FMLN, creemos que si es válido partir de que la unidad política es irrecuperable, de que el marxismo-leninismo ha pasado la historia ${ }^{58}$, de que estamos en un momento de cambios que implican decisiones importantes.

Si tomamos en cuenta la propuesta más elaborada, la de las FPL, ésta, desde nuestra perspectiva, contiene dificultades serias para su posible implementación, la primera de ellas se deriva de que resulta prácticamente imposible el poder llegar a la creación 
de un único partido de izquierda dada la diversidad de posiciones teóricas que hay al respecto, a lo sumo se podría pensar en la conformación de dos partidos de izquierda, uno que sea socialista democrático y el otro social-demócrata; más allá conduciría a una dispersión partidaria sin sentido, con pequeñeces.

Por otra parte, la propuesta de las FPL contiene un problema de génesis y es de que para muchos viene a ser la consumación del viejo sueño de Marcial, y de las FPL, de hacer de las FPL el verdadero partido vanguardia y hegemónico de la izquierda, ya que para él, "las FPL eran el núcleo marxista más grande y con más posibilidades para asumir dicha obligación." ${ }^{159}$ Sólo que adecuado a las actuales circunstancias, por ejemplo se dice que en la actualidad, 1994, dentro de la conformación del FMLN, el F2 aporta el $20 \%$ de los niveles de organización, e! F3 tiene el restante $80 \% .{ }^{60}$ Si tomamos en cuenta que las FPL son la agrupación más grande, la ERP ocupa la segunda posición, que la RN y el PCS son más o menos de la misma dimensión y que el PRTC es la agrupación más pequeña. A partir de esta información se pueden inferir los siguientes datos: al ERP le corresponde un 14\%, a la RN y PCS $6 \%$ respectivamente, al PRTC un 3\%, quedando para las FPL un aproximado de $70 \%$. De esta manera el F2 se queda con $20 \%$ y el F3 con $80 \%$.

De nueva cuenta encontramos que el núcleo mayor es el de las FPL. Para los miembros de las restantes organizaciones de izquierda, en caso de operarse la propuesta hecha por ellos, serían las FPL las que tendrían la mayoría y con esta situación se cumpliría el sueño de Marcial Por esta situación es que se considera que la propuesta de las FPL tiene un problema de génesis.

Por otra parte, consideramos que seguir aferrados a mantener el nombre de FMLN, ya sea para un nuevo partido o para lo que quede de él, no es lo más conveniente. Desde que se estaba en el proceso de negociación, cuando se dijo que la participación política de la estructura político-militar de Ia guerrilla sería a través de un partido político que se llamaría FMLN, lo consideramos un craso error, ya que con dicho nombre se alejarían posibilidades de atraer a nuevos sectores y lo único que se estaría logrando con ello sería el de asegurar lo que ya se tenía seguro, por otra parte, 
el hecho de que el FMLN estuviera asociado directamente con una de las partes beligerantes, provocaría una facilidad para la identificación del adversario político en la campaña electoral.

Dado que dicha situación se dió, es oportuno, hoy que se presenta la ocasión, de cambiar de nombre. Esta situación no debe ser vista como un entierro del FMLN, por el contrario, su nombre debe prevalecer, tiene un lugar distinguido en la historia y ello debe ser conservado, por lo tanto es oportuno no seguirlo utilizando, y ensuciándolo, en la arena político-partidista. Muchos partidos, después del derrumbe del muro de Berlín, se han visto en la necesidad de cambiar su nombre histórico y no por ello perdieron identidad o arraigo.

La identidad de la izquierda se encuentra en luchar por la justicia social, debe tener presente que sólo se considera que alguien es un ciudadano digno cuando gana un salario justo y suficiente para satisfacer sus necesidades de reproducción material y espiritual, para él y su familia, que sepa leer y escribir, que tenga un hogar digno, que tenga asistencia hospitalaria y médica, que tenga espacios de placer y descanso. En estos ámbitos, queda un tremendo reto para las opciones de izquierda. El Salvador ha avanzado bastante en lo que se refiere a libertades políticas, pero le falta mucho en el aspecto social y la única fuerza que tiene capacidad para hacer que se avance en este camino es la izquierda. Es necesario que se plantee la necesidad de fortalecer la sociedad civil, para que le sirva de contrapeso al Gobierno.

Este aspecto es definido por Weffort como el de la necesidad de impulsar la Democracia Social, que la caracteriza como aquella donde se presentan las siguientes características: "a) una clase trabajadora muy bien organizada, b) un alto grado de consenso para el respeto de las cuestiones decisivas para el desarrollo socio-económico de un país, c) que se tenga una sociedad con capacidad de planeamiento, d) también se espera que las clases sean capaces de compartir responsabilidades y colaborar en la administración de la sociedad... para que la Democracia Social tenga un asidero real se necesita que el Estado tenga la capacidad de intervenir en lo económico, a diferencia del Estado Neoliberal, que resulta incapaz de redistribuir a los social y políticamente integrados, ya no se diga de los que se encuentran al margen."61 
Por otra parte, retomando algunas ideas de Touraine sobre la democracia, para él "La Democracia sólo es fuerte cuando somete al poder al respeto irrestricto de derechos cívicos, definidos cada vez con mayor amplitud en términos cívicos, sociales, económicos y culturales. Se debe combatir el poder absoluto. No existe Democracia si no hay una sociedad abierta a todos los actores sociales; sino hay reconocimiento de derechos fundamentales; sino hay representatividad social de los dirigentes y de su política; sino hay conciencia ciudadana, en el sentido de pertenencia a una colectividad fundada en el derecho. No puede haber libertad política si el poder no está limitado por un principio superior a él, mismo que se opone a que sea absoluto. Si las desigualdades sociales son tan grandes, que posibilitan que los habitantes no tengan el sentimiento de un bien común, la democracia carece de fundamento. Para que sea fuerte es preciso que exista igualdad de condiciones y de una conciencia nacional."62

Como puede apreciarse, la cita anterior se adecúa perfectamente a las condiciones prevalecientes en la sociedad salvadoreña, incluso después de los Acuerdos de Paz, así que para que se puedan modificar es preciso luchar por ello, y la única ideología que lo puede realizar se encuentra del lado de la izquierda.

El espacio para los partidos de izquierda es la de buscar el Socialismo Democrático, donde debe prevalecer un sentimiento de un socialismo no de sistema sino de valores, ya vendrán tiempos mejores para pensar en el socialismo como sistema.

\section{En política de alianzas y pactos ¿qué se puede esperar?}

Zl futuro para las fuerzas de oposición, izquierda y centro, se -1 presenta como de muchos retos y definiciones claras. De una cosa se puede estar completamente seguro y es de que ninguna fuerza política por sí sola es capaz de enfrentarse electoralmente a ARENA, la única manera que queda es la de una política de alianzas claras con este firme propósito.

La historia política salvadoreña, en los últimos cincuenta años nos indica que existe una preeminencia de la derecha y que los pocos momentos donde se le ha hecho mella, es cuando se han unido las fuerzas del centro e izquierda. La UNO jugó un papel 
importante en este ámbito, el Foro Popular también hizo lo suyo, el agrupamiento surgido en COPAZ también ha posibilitado que la implementación de los Acuerdos de $\mathrm{Paz}$ no queden únicamente al libre albedrío de la derecha. El último caso que se tiene a este respecto es la lucha que se dio a nivel de la Asamblea Legislativa para la conformación de la nueva Corte Suprema de Justicia, donde gracias al concurso de las fracciones del FMLN, PDC, CD y MU se logró que ARENA no hiciera lo que que eran sus intenciones con el nombramiento de los Magistrados, tal como lo había manifestado la Presidenta de la Asamblea.

Todo parece indicar que existe una especie de 'condena' a actuar juntos entre el centro e izquierda para hacer que el sistema político se democratice y para hacerle un serio contrapeso a las opciones de derecha. Cuando han actuado unidos o aliados se ha avanzado, mientras que cuando se han distanciado las cosas han ido de mal en peor, como en los años 80 , cuando de la división que se diera entre ellos, la guerra los enfrentó en bandos diferentes.

La tesis básica de LA TRENZA continúa teniendo validez, solo unidos se puede enfrentar a ARENA, en las próximas elecciones de 1997, que tienen la ventaja de ser legislativas y de concejos municipales, donde las posibilidades de llegar a un acuerdo se facilitan. En ningún momento se deben dejar llevar por cantos de sirena que indican que al menos se debe pensar en buscar unidad de propósitos; para las elecciones de marzo hubo quienes propusieron este tipo de acción, pero nos preguntamos ¿Acaso no había unidad de propósitos entre todas las fuerzas de oposición en el sentido de derrotar a ARENA? La respuesta es positiva, pero en donde estuvo la falla es que no hubo concreción de esa unidad de propósitos, ya que la oposición se presentó dividida, tal como se indicara antes, con lo cual se presentó como rival entre sí, situación que aprovechó ARENA para obtener los indiscutidos ganes electorales en marzo de 1994.

De allí que la premisa básica para enfrentar a ARENA debe descansar sobre un sentimiento anti-arenero por sobre todo; la Democracia Cristiana debe entender que es un partido con arraigo en las masas, que su política de alianzas y pactos se encuentra precisamente en ese ámbito y no en sectores de derecha, tal como 
lo hiciera con Concertación 94, que a la larga el único diputado que logró con dicho pacto, a los pocos días se definió por su lugar de origen, primero decretándose independiente y luego concertando con ARENA. A los restantes partidos de tendencia evangélica les sucede lo mismo, sus bases son populares, por tanto deben buscar alianzas y pactos con sectores populares.

Por ello, es que consideramos, de acuerdo con el gráfico $\mathrm{N}^{\circ} 1$, que para 1997, al menos debe darse la concreción de un FRENTE AMPLIO: TODOS CONTRA ARENA. Es lo que indica la lógica y la historia, que es la madre y guía de la acción. En otras palabras, se debe pensar en la Realidad objetivada en la Historia.

México. 30 Noviembre de 1994

\section{NOTAS}

1. Este trabajo responde a una especie de obligación moral que se tiene de analizar los resultados del proceso electoral de marzo de 1994, que resultó en una real apertura de la "Caja de Pandora', muchos aspectos de divisiones latentes salieron a flote, en la izquierda, en el centro y en la derecha. Se ha aprovechado el tiempo de estadía en México para poder hacer estas reflexiones, que si bien tienen esta dificultad, la de estar 'lejos' y no ver de cerca los acontecimientos, también tiene la bondad de que es menor la influencia que pudiera tener una participación más cercana.

En los días que han transcurrido de mayo a noviembre muchos cambios políticos se han operado, la sociedad salvadoreña continúa siendo tremendamente dinámica, que muchos cambios se dejan de lado y las perspectivas de análisis a futuro también son muy dinámicas, pero la verdad es que hay que estar atento a la dinámica de los sucesos, sólo de esta manera se comprende la historia.

Contiene reflexiones de cara a la propuesta de La Trenza, de cara al futuro, de cómo ir mejorando el proceso de democratización y de mejoramiento de la situación derivada de la firma de la paz, que no necesariamente implica el fin de las dificultades, sino que éstas, en no muchas ocasiones, cambian de perspectiva.

2. WEFFORT, Francisco. ¿Cuál Democracia?. FLACSO. Costa Rica. 1993.

3. LAZO, José Francisco "Escenarios posibles para las elecciones de 1994". Diario Latino. 22 de abril de 1993.

4. IBID.

5. IUDOP “La opinión de los salvadoreños sobre las elecciones. La última encuesta pre-electoral "Centroamericanos - ECA- $\mathrm{N}^{\circ}$ 545-546 Marzo-abril de 1994. Universidad Centroamericana. El Salvador. 
6. HANDAL, Schafik, Secretario General del Partido Comunista Salvadoreño. "Balance del evento electoral del 20 de marzo de 1994 y aspectos sobre le segunda vuelta" 26 de marzo de 1994. Mimeo. San Salvador, El Salvador.

7. OBACH, Javier. "¡Patria o gente. .. ! Análisis de la campaña televisiva de ARENA y de la Coalicion". Estudios Centroamericanos -ECA- $\mathrm{N}^{\circ}$ 545-546 Marzo-abril de 1994. Universidad Centroamericana. El Salvador.

8. LAZO, José Francisco. "La Trenza: estrategia electoral 1994". En Cuadernos Electorales $\mathrm{N}^{\circ} 1$ del IEJES y en Cuadernos de Educación Civica del CINAS. San Salvador, El Salvador. Febrero de 1993.

9. FMLN. "Mensaje del FMLN al pueblo salvadoreno en el día de la reconciliaci6n nacional". Diario Latino, 15 de diciembre de 1992. El Salvador. Citado por LAZO, en "La Trenza..."

10. LAZO, José Francisco. "La Trenza..." Op Cit.

11. LAZO, José Francisco "El sistema político salvadoreno y sus perspectivas: notas para la discusión". CINAS. El Salvador. 1992.

12. Sung Joo Han. "South Korea; Politics in Transition", en L. Diamons, J. Linz y S.M. Lipes (eds) Politics in Developing Countries: Comparing Experiencies with Democracy. Colorado, Boulder \& London. 1990. Citado por José Antonio Crespo en "Alternativas para la oposicion". En ENFOQUE-REFORMA $\mathrm{N}^{\circ} 44,9$ de octubre de 1994. México, D.F.

13. Esta es la primera ocasión que se conoce que un partido político salvadoreño decide utilizar este método para la determinación de sus candidatos.

14. En más de alguna ocasión personajes de la politica salvadorena, externaron algunas críticas sobre lo que implicaba LA TRENZA, más que todo por el nivel de dispersión (aparente como yo la defendia) que ella implicaba y que era preferible la presentaci6n de una estrategia única, con una sola bandera y que toda la oposicín se presentara bajo un trente, tal como la experiencia de la UNO de los años 70. Pero cuando salieron los pactos de la izquierda, lo que manifestaron fue que ello era peor que LA TRENZA, que el relajo que iban a causar y la dispersión del electorado sería mayúsculo. En mi caso, que voté en el municipio de San Salvador, tuve que hacerlo sobre tres logos distintos.

15. En una plática sostenida con uno de los miembros de la Cornisión Política del FMLN, sobre el por qué de este comportamiento de parte del FMLN, manifestaba que ellos como FMLN ya habían cedido bastante al aceptar que el candidato a presidente no fuera de ellos y que el candidato a vice-presidente tampoco pertenecía a alguna de las estructuras de ellos, pero que sí contaba con el consentimiento de las cinco organizaciones. Ante esta desventaja, ellos como FMLN, necesitaban contar con algo propio, presentarse con identidad propia, en otras palabras, y que habían considerado que para diputados y en la mayoria de alcaldías impulsarían a sus propios candidatos, surgidos de entre sus cuadros.

16. Lungo, Mario. "Explorando el lado oculto de los resultados electorales de 1994 en El Salvador". Ponencia presentada en el Latin American Center de la Universidad de California. Junio de 1994.

17. OBACH, Xajier. "iPatria o gente. ..". Op Cit.

18. IBID. 
19. IBID.

20. IBID.

21. IBID.

22. En la revista Estudios Centroamericanos ECA N N $^{\circ} 45-546$ de marzo-abril de 1994, que contiene un número monográfico sobre las elecciones de 1994, aparece una serie de artículos donde se hace un tratamiento de la izquierda como coalición, de igual manera la revista Proceso en sus diversos análisis hace un tratamiento similar. Ambas revistas son de la UCA. El Salvador. La información periodística en el exterior también realizó un análisis similar sobre la participación en las elecciones.

23. LUNGO, Mario. "El Salvador 1981-1984 la dimensión política de la guerra". UCA Editores. El Salvador, 1986.

24. ROJAS, Javier. "Conversaciones con el Comandante Miguel Castellanos". Miguel Castellanos es el seudónimo de Napoleón Romero García miembro de la comisión política de las FPL, que desertó a mediados de los 80 's. Para muchos ésto hace que descalifique lo que dice o afirma, pero de acuerdo con estudios sicológicos, las personas que declaran en estas circunstancias tratan de hacerlo de la manera más objetiva posible. Ademas, personas, que se retiraron de las FPL, que fueron consultadas sobre los hechos que narra, dicen que en su mayor parte responden a lo sucedido. Queda para que las personas que si conocieron de cerca los hechos que él relata, digan si son ciertos o falsos. Editorial UNSSA. El Salvador. 1988.

25. El ERP ha sido de todos los conformantes del FMLN, la organización de la cual se ha dicho que es la que tiene el menor desarrollo ideologico, situación que explica más claramente su actuación en términos pragmáticos, tal como ha sido su viraje hacia la socialdemocracia y su pleito con los marxistas-leninistas, a quienes en alguna ocasión J. Villalobos indicó que a él 'le hacían los mandados' y los califica de antisistema y de ser 'jurásicos'.

26. La pretensión de las FPL, el grupo más numeroso del FMLN, ha estado signada por tratar de hegemonizar al interior del FMLN, esta situación tiene su origen en las pretensiones de Marcial se llegar a ser el Comandante General del FMLN y en considerarse además la organización que cuenta con el mayor nivel de ideologización.

27. ROJAS, Javier "Conversaciones..." Op. Cit.

28. IBID.

29. Citas tomadas del articulo de José Antonio Morales". El suicidio de Marcial. ¿Un asunto concluido?". Oue retoma documentos oficiales de las FPL de esa época. Revista Estudios Centroamericanos ECA. No 549 de Julio de1994. El Salvador.

30. LUNGO, Mario "El Salvador 1981-1984..." Op. Cit.

31. LUNGO, Mario "EI Salvador en los 80: contrainsurgencia y revolución". FLACSO y EDUCA. CostaRica. 1990.

32. ROJAS, Javier "Conversaciones..." Op, Cit.

33. MORALES, José Antonio "El suicidio..." Op. Cit.

34. LAZO, José Francisco. "El sistema político..." Op. Cit.

35. Esta situación le fue manifestada por J. Villalobos al Dr. Ungo, indicándole que los análisis que ellos habian realizado les indicaban que con una exce- 
lente campaña lograria colocarse en el primer lugar de ías votaciones al candidato de la izquierda. en esa ocasión Ungo le dijo que era una premisa falsa, que a lo más que se podría aspirar era a obtener un $20 \%$ y que era algo más que imposible lograr que ARENA no lograra el primer lugar, y con ello la presidencia.

36. Tomado de una entrevista que Marta Harnecker le hiciera a J. Villalobos en 1989, que tuera publicada en la revista Estudios Centramericanos ECA $\mathrm{N}^{\circ}$ 485, de 1989, con el título de "La propuesta del FMLN: un desafío a la estrategia contrainsurgente". Citado por Carlos Acevedo en "Las elecciones generales de 1994: consolidación de la hegemonía de ARENA". Revista Estudios Centroamericanos $-E C A-\mathrm{N}^{\circ}$ 545-546 de marzo-abril de 1994. El Salvador.

37. Dentro del lenguaje que se utiliza en la Asamblea, cuando una fracción legislativa no tiene la capacidad, numérica, de imponer sus puntos de vista, pero hacen oír su punto de vista, se dice que 'hacen el grito del cuche', en reterencia a que el cerdo al momento de que va a ser ejecutado, se encuentra maniatado sin posibilidad de detenderse, hace un tremendo ruido con la boca, tratando de Impedir su ejecución. La situación es aplicada cuando se dice que una tracción tiene la razón pero no cuenta con los votos necesarios para imponerse en las votaciones.

38. ECA. Comentario aparecido en el número 550 de agosto de 1994. El Salvador.

39. Joaquín Villalobos manifestó "no sólo las FPL se aliaron con la ultraderecha en esta toma (del recinto legislativo). . . añadió que este episodio habia constituido la amenaza más grave que ha vivido el proceso de paz". Periódico La Jornada. 30 de septiembre de 1994. México.

40. La Jornada. 5 de octubre de 1994. México.

41. Excelsior. 6 de octubre de 1994. México.

42. La Jornada. 10 de octubre de 1994. México.

43. En la pasada legislatura aconteció algo similar, el PDC se resistió a estar representado en la Junta Directiva, según dicen por un capricho de Chávez Mena, porque quería la presidencia según dijeron algunos democristianos en ese momento, mientras que la Convergencia pasó a ocupar dos puestos de la directiva, ante esta situación, los diputados del PDC comenzaron a criticar duramente esta situación aduciendo que había habido un entendimiento con ARENA, por por ello dijeron que lo que habia era una convergencia arenera. Lo que se puede decir a este respecto es que la decisión de la Convergencia al final resultó acertada, es más a mediados de la legislatura el PDC solicitó integrar la Junta Directiva y fue rechazadar. La razón de estar representado en la Junta Directiva se deriva de que en esa instancia se 'cocinan' muchas cosas.

44. CASTRO DUARTE, Guido. "La realidad de los partidos políticos". Artículo aparecido en la página editorial de la Prensa Gráfica del $1^{\circ}$ de noviembre de 1994. El Salvador.

45. Comentario aparecido en la revista $E C A N^{\circ} 550$, de agosto de 1994 , bajo el nombre de ¿Sistema de partidos o caos de fragmentos políticos? 
46. CASTRO DUARTE, Guido. "La realidad de los ..." Op. Cit.

47. PROCESO. Intormativo Semanal N 616 Año 14, del 22 de junio de 1994. UCA. El Salvador.

48. PROCESO. Informativo Semanal No 610 Año 14, del 11 de mayo de 1994. UCA. El Salvador.

49. PROCESO. Informativo Semanal N ${ }^{\circ} 630$ Año 15, del 5 de octubre 1994. UCA. El Salvador.

50. BOURDIEU, Pierre. "Cultura y sociedad". Editorial Grijalbo. Mexico. 1992.

51. ACEVEDO, Carlos. "Las elecciones generales de 1994..." Op. Cit.

52. WEFFORT, Francisco ¿Cuál democracia? Op. Cit.

53. Comentario aparecido en El Diario de Hoy, titulado "Oposición sigue en crisis", responsabilizado por Martha Elena Ibarra e Ivonne Rivera, fecha 31 de octubre de1994. El Salvador.

54. SAMAYOA, Salvador. "Ejes de transtormación en los partidos durante la post-guerra". En Revista'Tendencias N $N^{\circ} 34$ Octubre de 1994. El Salvador.

55. Comunicado conjunto del MNR, ERP y RN "Agrupamiento Socialdemócrata", de fecha 28 de septiembre de 1994, sobre la toma de la Asamblea Legislativa por miembros desmovilizados de la Fuerza Armada.

56. FPL propuesta para la conformación de "Un Partido de Izquierda Democráti$c a "$. Hecho público en el Diario Latino del 16 de junio de 1994. Aparece también como documento en la Revista Estudios Centroamericanos ECA N9 549, Julio de 1994. El Salvador.

57. Ibid.

58. Si bien comprendemos que resulta difícil desligarse completamente de la ideología que se ha abrazado durante años y que además dio la sustentabilidad para iniciar el proceso de cambios en la sociedad salvadorena, con el planteamiento de la lucha armada. Pero de mayores consecuencias resulta el continuar aferrados a una ideología que demostr6 un total fracaso en su aplicación práctica, por ser antihistórica, antidemocrática y que no condujo a un estado de prosperidad y abundancia. Por ejemplo, como se debe sentir uno de los líderes del FMLN, quien en una ocasión emulando al maestro Lenin, entró por tren a El Salvador, al igual que aquél lo hiciera cuando regresó a Rusia a iniciar la Revolución Bolchevique.

59. MORALES C. José Antonio "EI suicidio de Marcial.." Op. Cit.

60. Datos proporcionados en una charla que diera, en la UCA, un miembro de la Comisión Política de las FPL, en mayo de 1994.

61. WEFFORT, Francisco. "¿Cuál Democtacia?". Op. Cit.

62. TOURAINE, Alain. "Crítica de la modernidad". Editorial Temas de Hoy - Ensayos. Madrid. España. 1993. 


\section{ANEXOS}

\section{ANEXO No 1 \\ ESCRITO DE GRAMSCI, de 1923}

"Nosotros no conocemos Italia. Peor todavía, no tenemos los instrumentos adecuados para conocer Italia tal como es realmente, y entonces nos encontramos en la casi imposibilidad de formular previsiones, de orientarnos, de establecer líneas de acción con cierta probabilidad de acierto... somos completamente ignorantes, estamos desorientados... He aquí nuestra debilidad, he aqui la principal razón de la derrota de los partidos revolucionarios italianos: no haber tenido una ideologia, no haberla difundido entre las masas, no haber fortificado las conciencias de los militantes con certezas de carácter moral y psicológico. . . Lamentablemente la concepción no la tenemos, y esta es la razón de todos estos errores teóricos, que luego se reflejan en la práctica y que nos han llevado hasta hoy a la derrota... ¿Qué hacer entonces? ¿Por dónde debemos comenzar? Veamos: a mi parecer, es necesario comenzar justamente por aqui, por el estudio ... reunirse, comprar libros, organizar lecciones y conversaciones sobre este tema, fomarse criterios sólidos de investigación y de examen y criticar el pasado para ser más fuertes en el futuro y vencer."

Cita tomada del libro: "Gramsci y la Construcción del Socialismo". Del autor Rafael Díaz Salazar. UCA Editores. El Salvador. 1993. 


\section{ANEXO N ${ }^{\circ} 2$ \\ COMUNICADO DEL FMLN, SOBRE LOS ACONTECIMIENTOS DEL 1 DE MAYO EN LA ASAMBLEA LEGISLATIVA}

(3 de mayo de 1994)

1- Durante varias reuniones la Comisión Política del FMLN examinó detalladamente las condiciones de funcionamiento y organización de la nueva Asamblea Legislativa y hubo opinión unánime de que su Reglamento Interno, tal como está, impone un régimen presidencialista que no refleja el carácter representativo proporcional de este órgano del Estado y cierra espacios a un desempeño democrático de la labor parlamentaria y legislativa.

Por esta razón se acordó buscar consensos con todos los partidos políticos y sus diputados para reformar el Reglamento Interno, a objeto de democratizar la Asamblea Legislativa, demandando entre otros puntos una integración de su Junta Directiva que refleje con la mayor aproximación las proporciones surgidas de las elecciones el 20 de marzo.

2-Cuando estábamos realizando estas conversaciones sorpresivamente ARENA hizo aprobar en la última sesión plenaria de la Asamblea anterior (el 29 de abril por la noche), una reforma puntual del Reglamento, estableciendo en diez el número de miembros de la Directiva y otorgándole voto doble al Presidente (ahora Presidenta), con lo cual ARENA se adjudicó una mayoría que no le dió el pueblo con sus votos y se aseguró que en ningún caso la oposición podrá tomar decisiones en la Directiva sin su aprobación. Esta reforma empeoró el carácter presidencialista anti-democrático del Reglamento.

3- Esta situación se vela agravada por la ruptura por parte de ARENA y algunos aliados suyos del consenso alcanzado en COPAZ para reformar la Constitución en los términos recomendados por la Comisión de la Verdad.

El mensaje era claro: ARENA ha decidido imponer su hegemo- 
nía y dar la espalda a compromisos derivados del Acuerdo de Chapultepec.

4- Frente a esta nueva situación, la Comisión Politica, ampliada con la participación de diputados electos del Frente, decidió por mayoria no participar en la Directiva de la Asamblea Legislativa hasta que el Reglamento sea reformado y anunciar que presentaremos próximamente un proyecto de decreto con tal fin.

Por eso mismo, la Comisión Política del FMLN se abstuvo de aprobar ningún nombre o lista de personas como candidatos a ocupar cargos en la Directiva de la Asamblea Legislativa.

5- A pesar de ello, siete Diputados de nuestra fracción legislativa votaron durante la elección de Directiva en el plenario del primero de mayo y dos de ellos, Ana Guadalupe Martínez y Eduardo Sancho (Fermán Cienfuegos), aceptaron cargos de vicepresidente y secretario respectivamente.

6- Debe quedar claro para todos, en consecuencia, que estos Diputados no representan a la Fracción de Diputados del FMLN, ni al FMLN mismo en la Directiva de la Asamblea Legislativa y que ninguno de sus actos, opiniones o compromisos nos obligan o nos comprometen.

La representación del FMLN ha sido usurpada de esta forma, con apoyo de los votos de los diputados de ARENA.

7- El Coordinador General de FMLN plantea este problema a la deliberación de las bases y organismos del Partido para tomar las decisiones que corresponda.

8- El FMLN continuará fiel a su ideario democrático-revolucionario, a los intereses populares, y al programa de democratización y justicia social contenido en el Acuerdo de Chapultepec. en su carta de Principios y Objetivos y en su Plataforma Programática y redoblará su lucha por lograr su cumplimiento

Schafick Jorge Hándal

Coordinador General FMLN

Nota: el contenido de esta nota fue ratificado en su totalidad con la reunión de Consejo Nacional del FMLN que se celebró el 10 de mayo 


\section{ANEXO No 3 \\ CARTA DEL CONSEJO NACIONAL DE LA ERP}

San Salvador, 27 de mayo 1994

Cro. Coordinador General del FMLN, Schafick Jorge Handal

Cros. Comisiones Políticas y Direcciones del PCS, FPL, PRTC y

Cros. que están realizando reuniones municipales y departamentales

Presentes

Estimados Compañeros:

Reciban cordiales saludos.

El día 21 de mayo, nos reunimos los miembros del Consejo Nacional del Partido Expresión Renovadora del Pueblo, ERP, con la asistencia de 88 de los 100 miembros que componen nuestro Consejo y y resolvimos por unanimidad dirigirles la presente carta y comunicarles lo sigitiente:

$1^{\circ}$ Que respaldamos totalmente a nuestra Dirección Nacional y a nuestros diputados por lo actuado el $1^{\circ}$ de mayo en la Asamblea Legislativa y el consiguiente debate y crisis que ésto ha motivado. La posición adoptada por los compañeros es consecuente con nuestra línea política y se inscribe dentro del marco lógico de la autonomía que los partidos miembros del FMLN deben tener en la nueva realidad del país.

$2^{\circ}$ Que consideramos que la salida a este problema es la firma de un nuevo pacto político de las cinco organizaciones, por haberse agotado el que mantuvimos para la guerra.

$3^{\circ}$ Que nos unimos a los contenidos de la carta enviada por la Comisión Política de la Resistencia Nacional, firmada por el compañero Eduardo Sancho y su propuesta de iniciar ya la discusión de un nuevo pacto.

$4^{\circ}$ Que consideramos que las medidas de suspensión aplicadas son ilegales porque violan los procedimientos establecidos por los estatutos y van en contra de un derecho constitucional que tienen 
los diputados. Son autoritarias porque se contradicen con la más elemental y civilizada conveniencia democrática. Sobre este punto haremos llegar nuestro alegato jurídico, el cual presentaremos a las instancias correspondientes del FMLN y del país.

$5^{\circ}$ Teniendo en cuenta lo anterior, proponemos como base del nuevo pacto político del FMLN, con los siguientes puntos:

a) Establecimiento claro de que el FMLN es una alianza de partidos y no un sólo partido.

b) Reafirmar la autonomía de los partidos que componen el Frente y el derecho de éstos a agruparse y unificarse como tendencias que puedan manejar sus propios planteamientos programáticos y línea política.

c) Respeto al derecho de los diputados de actuar conforme su conciencia y a la línea política con que militan.

d) Establecimiento de ejes de coincidencia, a partir de la defensa de los Acuerdos de Chapultepec, la propuestas de la fracción legislativa del FMLN y todos aquellos puntos que permitan avanzar en la democratización del país y obtener resultados concretos para los sectores más necesitados.

e) Elaboración de nuevos estatutos y reglamento que se ajusten al nuevo pacto político, a la existencia de cinco partidos y de las dos grandes tendencias ideológico-políticas que hay dentro de nuestro Frente.

$6^{\circ}$ Les comunicamos que hemos acordado no asistir a las reuniones municipales y departamentales que están realizando los compañeros de las FPL, PCS y PRTC, por las siguientes razones:

a) Dichas reuniones no admiten el debate político que es lo que históricamente ha existido entre nosotros...

b) No es correcto discutir el problema con un enfoque disciplinario, porque nunca hemos sido un sólo partido y siempre hemos tenido diferencias. No aceptamos esas reuniones porque no buscan consensos políticos que nos unan, sino que intentan aplicar criterios de mayoría y minoría que no son válidas para discutir un nuevo pacto. 
c) Ni en los momentos más dificiles, con problemas reales graves y hechos de altisimo costo politico para todo el FMLN, se adoptaron medidas disciplinarias contra organizaciones o miembros de organizaciones por decisión colectiva de organismos del Frente. No queremos legitimar el proceso que se ha abierto porque lleva a la división del Frente. Nuestros Estatutos configuran que el FMLN es pluralista y se compone de cinco organizaciones.

d) Es falsa la idea de que estas reuniones tengan la posibilidad de modificar las posiciones de los militantes de los partidos. No hay aun condiciones y madurez para eso. Por lo tanto el criterio real y objetivo es que la gente adopta la posición conforme a la línea de su partido. Por ello no creemos que un problema de cinco partidos con posiciones políticas diferenciadas se resuelva aplicando criterios de consulta a las bases como si fueramos un sólo partido.

e) Por otro lado, el debate no ha sido correctamente orientado y se han exacerbado los ánimos, lo cual nos expone a discusiones más emotivas que maduras y a riesgos de problemas por hacer del debate una movilización de barras. Nosotros no creemos en ese método de presiones y no queremos hacerle el juego a actos de prepotencia y falta de madurez.

f) Se ha convertido en pecado determinadas posiciones y se alienta un fanatismo irracional, que impide escuchar. No rehuimos al debate político, nos gusta el debate y por ello hemos sido y seguiremos siendo partidarios del debate abierto al pueblo. Recordamos en el pasado, cuando RN y ERP, proponíamos que el debate debía abrirse al público ésto era visto como negativo. Creemos que debemos darle continuidad al debate vía medios de comunicación para someter a prueba nuestras posiciones no sólo frente a las bases, sino de todo el pueblo, que es al que nos debemos.

En el plano político queremos aclarar que el ERP está por una renovación del FMLN, que nos permita competir con una derecha que está modenizándose y en un acelerado cambio. Si en el FMLN siguen predominando estilos y planteamientos del pasado, fracasaríamos en futuros eventos electorales. 
Estamos buscando como ERP, la forma correcta de ganarle batallas políticas a la derecha...

Antes de prejuzgar emocionalmente mal intencionadamente las posiciones políticas que nosotros mantenemos, al calificarlas de "traición", "abandono de los intereses populares", "alianza con la derecha", etc., debe reflexionarse que si un contingente histórico de militantes que tienen 24 años de lucha en las calles, en la clandestinidad, en las cárceles, en las montañas, en la negociación y en las elecciones, están planteando una posición distinta, debe haber una razón política poderosa para ello. Es ridículo pensar que de la noche a la mañana traicionen y ésto sea una simple pelea por cargos.

... Nuestras diferencias son de orden político y deben verse maduramente sin fanatismo que a nada conducen y a nadie impresionan ya. A nosotros no nos preocupa la crítica fanatizada desde posiciones extremistas. . . Rechazamos ese viejo estilo de izquierda a lo largo de la historia, de llamar renegados, traidores $\mathrm{e}$ indisciplinados a los que proponen nuevas ideas.

Tenemos otras ideas, pensamos distinto y creemos que la manera de hacer valer la democracia y el interés de las mayorías populares es ahora diferente; respetamos y tenemos incluso coincidencias con el PRTC, el PCS y las FPL, pero creemos que están equivocados en puntos sustanciales y de que sus posiciones pueden provocar, como ya ocurrió en las pasadas elecciones, nuevas victorias de la derecha en el país...

Por ello nos pronunciamos por mayor autonomía y así probar nuestras verdades y errores en la práctica tal como lo hemos siempre a lo largo de los últimos 24 años.

Como por ejemplo, cuando discutiamos:

Si era correcta o no la lucha armada en 1970;

Si unidad de las fuerzas revolucionarias o vanguardia revolucionaria única en 1980;

Si insurrección o ejecución de la Ofensiva de enero en 1981 o Guerra Popular Prolongada;

Si Ofensiva Final al Tope fue para buscar el desenlace de la 
guerra o simplemente una ofensiva militar más en 1989;

Si nuestro programa de realizaciones democráticas es nuestro programa estratégico o es sólo una táctica para mejorar posiciones, 1990;

Si hablar con Estados Unidos era traición o era una necesidad política para terminar la guerra, 1990;

Si la negociación y el Acuerdo de Chapultepec son una revolución o son simplemente un desenlace de la guerra con definición o revolución pendiente, enero de 1992;

$\mathrm{Si}$ aceptar clara y abiertamente el mercado y la propiedad privada es ser revolucionarios realistas o ser neoliberales derechistas y si rechazar el marxismo=-leninismo y plantear que el socialismo real fue un total fracaso es una necesidad histórica para renovar a la izquierda o es una traición (a propósito de las críticas al libro del Cro. Joaquín Villalobos, Una Revolución en la Izquierda Para Una Revolución Democrática, en 1992);

Si debíamos buscar una fórmula más amplia que evitar a la victoria de ARENA en las elecciones de marzo del 94 o si era posible ganar éstas con una fórmula de izquierda.

$\mathrm{Ni}$ antes ni ahora consideramos haber tenido o tener la verdad absoluta, pero la historia fue dando la razón a quien la tuvo y por eso llegamos hasta aquí. Hay que darle una nueva oportunidad a la historia.

Creemos que los instrumentos de análisis son de uso universal para cualquier corriente política de izquierda o de derecha. Los que hacen de las teorías dogmas de los que no pueden abdicar ni desembarazarse, aun sabiendo que es un grave error, hacen religión y no política. La política es el arte de lo posible.

No puede una utopía fracasada y sin viabilidad histórica hacernos perder fuerza y llevarnos a cometer errores de enfoque perdiendo de vista la realidad inmediata. No podemos regirnos por miedos ideológicos a desviaciones revolucionarias. No puede ser más importante ser fieles a una falsa pureza revolucionaria que el producir resultados concretos al pueblo. Igual no puede ser más importante ser fieles decidir nuestros pasos a partir de la desconfianza y los temores al que se considera enemigo de clase, que 
actuar a partir de poner la confianza en nuestras propias ideas y la realidad.

El ERP ha presentado sus tesis sobre la propiedad privada social, el equilibrio entre sociedad civil, estado y mercado para hacer viable un proyecto revolucionario realista que no necesita ser anti-capitalista y anti-imperialista para ser puro y que no necesita negar a los adversarios su derecho a existir y a tener poder para que sea popular.

Las contradicciones que tenemos a la hora de actuar en situaciones como la de la Asamblea el $1^{\circ}$ de mayo y otras, tienen por base estas diferencias, no surgen esos problemas de la nada. El ERP no ha buscado la definición socialdemócrata por razones teóricas o doctrinarias, sino porque esa corriente política parte más de la realidad que de la utopía y porque de esa manera mostramos claramente nuestro cambio a los soctores populares y no populares que nos rechazan y nos temen, por considerarnos un proyecto anti-sistema y extremista que no da seguridad.

Es un error creer que los sectores populares están automáticamente con nosotros por razones ideológicas. Al contrario, por razones ideológicas nos rechazan amplias capas populares. Por ello es importante jugar en serio y de buena gana dentro y con las reglas del juego del sistema. Sólo así podemos ganar batallas en la arena electoral, que es donde ahora se decidirá el futuro de cada fuerza política.

Cada quien debe pagar los costos y beneficios que le trae el nombre, el color y los conceptos que tienen sus propias definiciones ideológicas. Los que se consideran comunistas y marxistasleninistas deben ganarse el apoyo del pueblo, levantando esas banderas, clara y abiertamente y los que nos consideramos socialdemócratas y que hemos rechazado el marxismo-leninismo debemos hacer igual, como también deben hacerlo los que no quieran definirse o no decir cómo se definen.

A partir de allí debemos pactar la alianza entre unos y otros. No es admisible que sigamos alentando posiciones oportunistas a las que la indefinición o la aparente definición del FMLN, como fuerza de centro izquierda hacia afuera, les beneficia, no podemos ser confesos democráticos hacia afuera y antisistema hacia aden- 
tro con las bases. Es importante que cada uno busque la identidad que considcra tiene más potencial político popular nacional e internacional.

Al ERP se le ha juzgado como traidor, por decir que no somos antisistema. Los que nos juzgan así, deben buscarle apoyo político a su planteamiento antisistema y a su proyecto histórico sin ocultarlo. Nosotros los respetamos pero rechazamos ser compañeros de viaje de un proyecto que no se confiesa abiertamente. Nuestras tesis de mediano y largo plazo están expuestas claramente en todos los documentos del ERP.

Finalmente reiteramos nuestro respeto a los militantes de todas las organizaciones del FMLN y sus direcciones. La contradicción es el motor de la historia, sin ella no hay desarrollo, por ello no vemos fatal esta situación.

Manifestamos que debe abrirse la discusión sobre bases políticas y respetarse los dirigentes que las organizaciones han electo para que los representen en el FMLN y hacer posible así un intercambio político realmente democrático.

\section{Consejo Nacional del ERP}


GRAFICO N" 1

EVOLUCION DELA POLITICA DEALIANZAS DELAIZOUJRRDA YEL. CENTRO POLLTICOS

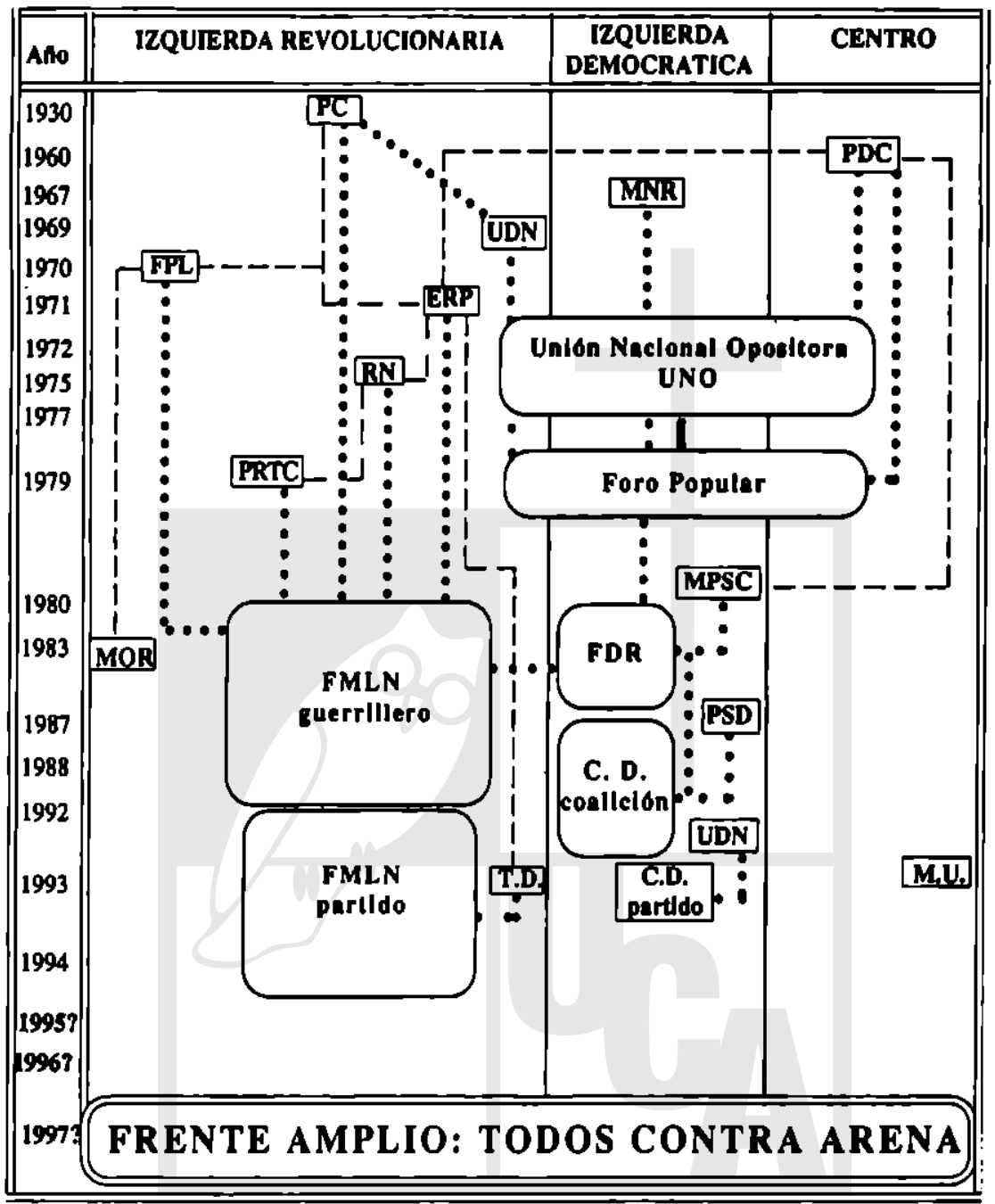

- - - - Significa escisión

....... Significa que se ha coaligado

Coalición y nombre que adquiere

FUENTE: elaboración propia sobre la base del desenvolvimiento de cuda una de la orgunizaciones 


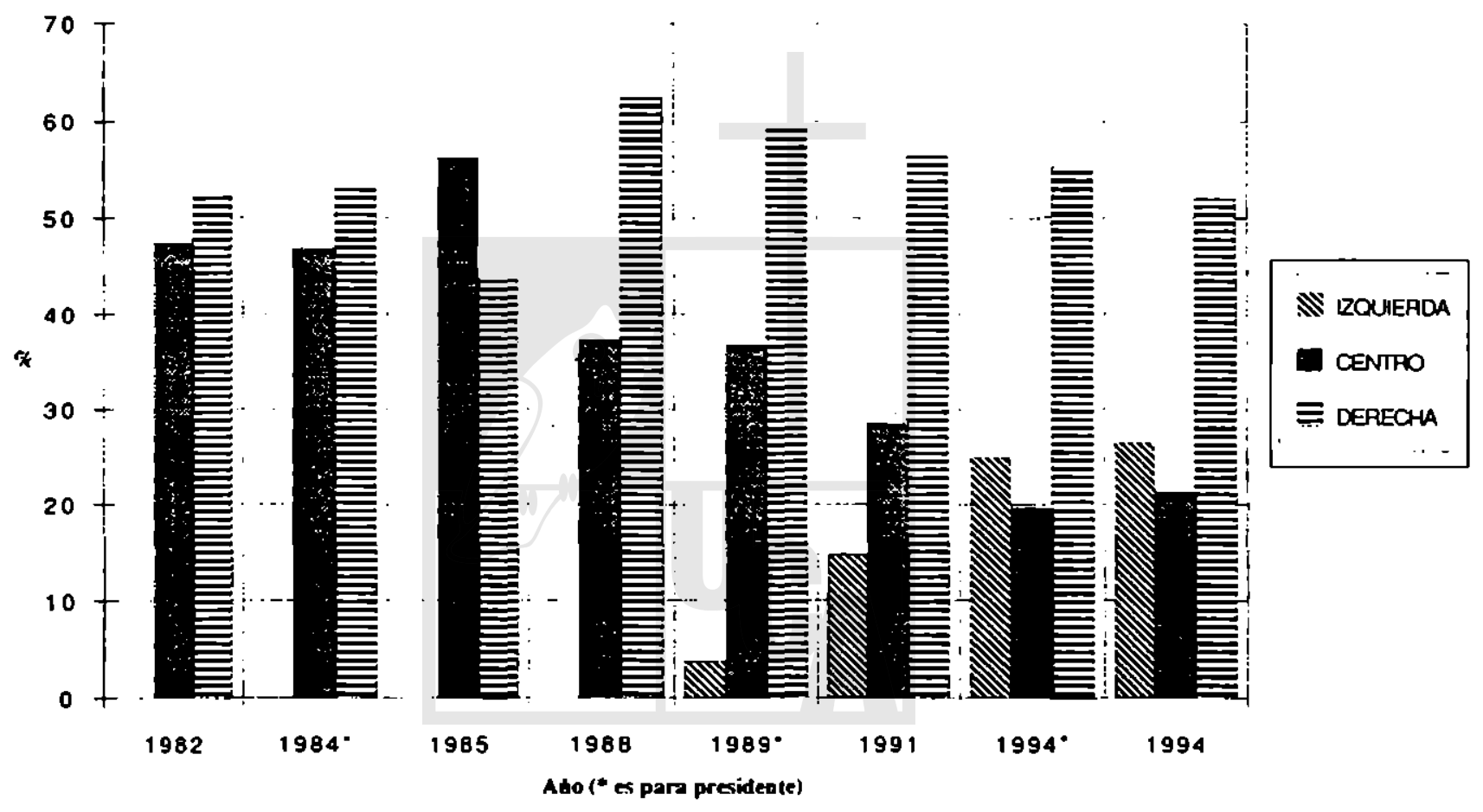




\section{CLADRO N² 1}

RESULTADOS DE SONDEOS DE OPINION PRE-ELECTORALES (IUDOP)

(porcentajes absolutos y ajustados*)

\begin{tabular}{|c|c|c|c|c|c|c|c|c|}
\hline & \multicolumn{2}{|c|}{ Junio 1993} & \multicolumn{2}{|l|}{ Octubre 1993} & \multicolumn{2}{|l|}{ Diciembre 1993} & \multicolumn{2}{|l|}{ Febrero 1994} \\
\hline & $\%$ & $\%$ ajustado & $\%$ & \% ajustudo & $\%$ & $\%$ ajustado &.$\%$ & $\%$ ajustudo \\
\hline ARENA & $26 .(x)$ & 49.24 & 27.40 & 55.58 & 20.00 & 53.48 & 34,00 & 53.13 \\
\hline COALICION - FMLN & 11.00 & 20,83 & 11,40 & 23,12 & $12 .(x)$ & 32.09 & 16.00 & $25 .(x)$ \\
\hline PDC & 12.30 & 23.30 & 7,80 & 15.82 & 3.50 & 9.36 & 11.00 & 17.19 \\
\hline $\mathrm{PCN}$ & $2(x)$ & 3.79 & 2.00 & +.06 & 1.00 & 2.67 & 1.60 & $2.51)$ \\
\hline $\mathrm{MU}$ & & & & & 0.30 & 0.80 & 0.80 & 1.25 \\
\hline MSN & & & & & 0.30 & $0 .(0)$ & 0.80 & 1.25 \\
\hline MAC & (1.2) & 0.38 & 0.00 & $0,(0)$ & 0.10 & 0.27 & 0.20 & 0.31 \\
\hline MNR & 0.80 & 1.52 & 0.00 & $11 .(x)$ & 0.30 & 0.80 & & \\
\hline Ninguno & $17 .(x)$ & & 11.70 & & $7 .(x)$ & & 3.00 & \\
\hline Nos sabe/No respunde & 30.2(1) & & 39.00 & & $5.5 .(x)$ & & 33.00 & \\
\hline TOTAL & $100 .(x)$ & 100,00 & 100.00 & 100.00 & 100.00 & 100.00 & 100,00 & $I(00,(x)$ \\
\hline
\end{tabular}

* lo ajustado es referente a los que si manifestaron intención de volo

FUENTE: IUDOP. Sobre la base de diversos sondeos de opinión realizados previo a las elecciones de 1994. UC A. San Salvador. 
CUADRO N*2

VOTOS POR PARTIDO POLITICO Y TENDENCIA

(elecciones de 1982 a 1994)

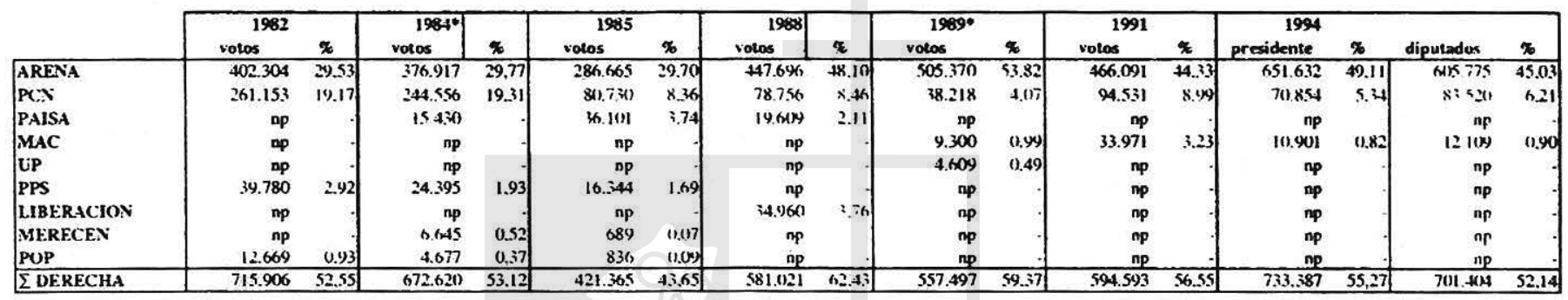

\begin{tabular}{|c|c|c|c|c|c|c|c|c|c|c|c|c|c|c|c|c|}
\hline AD & 101.358 & 7.44 & 43.429 & 3.47 & 35.565 & 3.68 & 16.211 & 1.74 & 4.363 & 0.46 & 6.798 & 0.65 & $n p$ & & $\mathrm{np}$ & \\
\hline PDX: & 546.261 & 41.10 & 549.727 & 43.41 & 505.338 & 52.35 & 326.761 & \$..11 & $\$ 38.369$ & .6. 113 & 244.1829 & $27 . \% 6$ & 2150136 & 16.27 & 241 451 & 17.87 \\
\hline PAR & $n p$ & & $n p$ & & $2 \% 3$ & 0.31 & $5 .(15.5)$ & 0.4 & 3.207 & 11.4 & $n p$ & & $n p$ & & up & \\
\hline Mi: & np & & ap & & $n p$ & & $\mathrm{np}$ & & np & & np & & 31.425 & 2.41 & i3.5111 & 2.49 \\
\hline MSN & $n p$ & & $n p$ & & $n p$ & & $n p$ & & $n p$ & $\therefore$ & $n p$ & & 15.954 & 1.05 & $12 \times 27$ & 10.95 \\
\hline E CENTRO & 647.576 & 47.53 & 593.6 .56 & 46.88 & 543.866 & 56.35 & $.37 .98 \mathrm{~s}$ & 37.34 & 345.939 & 36.84 & .300 .827 & 28.61 & $261 . \times 211$ & 19.73 & $2 x_{1}, 7 \times K$ & 21.32 \\
\hline
\end{tabular}

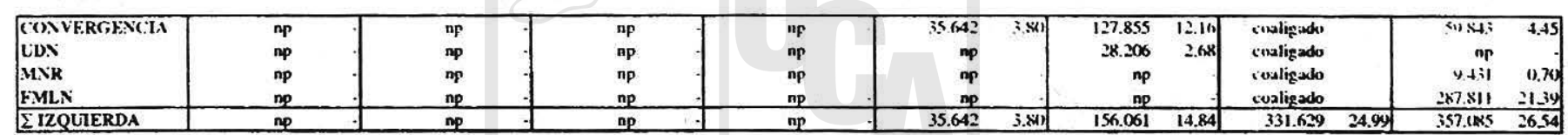

I IZOUIERDA

no 1

np

FUENTE: sobre la base de resultados oficiales del organismo gubermamental encargade de las elecciones. 


\section{CUADrONa 3}

\section{CUADRO № 3}

VOTACION PARA PRESIDENTE POR DEPARTAMENTO (segunda vuelta. abril 1994)

\begin{tabular}{lrrrrrr}
\hline & ARENA & COALICION & $\begin{array}{c}\text { VOTOS } \\
\text { VALIDOS }\end{array}$ & $\begin{array}{c}\text { ARENA } \\
\%\end{array}$ & $\begin{array}{c}\text { COALICION } \\
\%\end{array}$ \\
\hline San Salvador & 238.865 & 145.301 & 384.166 & 62.18 & 37.82 \\
Santa Alna & 78.395 & $\mathbf{3 8 . 4 5 1}$ & 116.846 & 67.09 & 32.91 \\
San Miguel & $\mathbf{5 6 . 7 7 2}$ & 18.783 & 75.555 & 75.14 & 24.86 \\
La Libertad & 91.747 & 41.076 & 132.823 & 69.07 & 30.93 \\
Usulután & 44.193 & 17.743 & 61.936 & 71.35 & 28.65 \\
Sonsonate & 61.343 & 28.216 & 89.559 & 68.49 & 31,51 \\
La Unión & 32.234 & 7.830 & 40.064 & 80.46 & 19.54 \\
La Paz & 43.539 & 16.468 & 60.0107 & 72.56 & 27.44 \\
Chalaterango & 31.479 & 13.418 & 44.897 & 70.11 & 29,89 \\
Cuzcattán & 32.891 & 12.540 & 45.431 & 72.40 & 27.60 \\
Ahuachapán & 39.911 & 14.871 & 54.782 & 72.85 & 27.15 \\
Morazán & 21.743 & 7.143 & 28.886 & 75.27 & 24.73 \\
San Vicente & 21.963 & 11.136 & 33.099 & 66.36 & 33.64 \\
Cabarias & 23.189 & 6.004 & 29.193 & 79.43 & 20,57 \\
& & & & & \\
\hline TOTAL & 818.264 & 378.980 & 1.197 .244 & 68.35 & 31.65 \\
\hline
\end{tabular}

CUADRO N

VOTACION PARA DIPUTADOS POR DEPARTAMENTO (marzo 1994)

\begin{tabular}{|c|c|c|c|c|c|c|c|c|c|c|}
\hline & ARENA & FMLN & CD & MNR & PDC & $\mathrm{PCN}$ & $\mathbf{M U}$ & MSN & MAC & $\begin{array}{c}\text { VOTOS } \\
\text { VALIDOS }\end{array}$ \\
\hline San Sulvador & 188.690 & 124.196 & 23.711 & 2.571 & 47.896 & 16.468 & 12.005 & 3.352 & 2.317 & 421.206 \\
\hline Santa Alra & 58.702 & 28.685 & 5.933 & 816 & $28.04 ?$ & 6.978 & 2.266 & 1.255 & 989 & 133.667 \\
\hline San Miguel & 37.317 & 12.575 & 3.210 & 952 & $19.70 \mathrm{~K}$ & 5.045 & 2.467 & 1.388 & 943 & 83.605 \\
\hline La Libertad & 72.673 & 33.288 & 7.273 & 1.327 & 23,700 & 6.644 & 4.198 & 968 & 1.745 & 151.816 \\
\hline Usulután & 31.651 & 11.440 & 4.007 & 549 & $15.17]$ & 4.242 & 1.843 & 1.897 & 987 & 71.787 \\
\hline Sonsonate & 45.700 & 17.715 & 5.079 & 664 & 24.871 & 8.112 & 1.825 & 941 & 1.136 & 106.043 \\
\hline La Uunion & 20,946 & 3.141 & 1.705 & 235 & 13.833 & 3.359 & 1.491 & 473 & 786 & 45.969 \\
\hline LaPaz & 31.836 & 10.906 & 1.552 & 269 & 13.896 & 7.333 & 1.622 & 476 & 439 & 68.329 \\
\hline Chalateinango & 22.640 & 9.492 & 1.225 & 191 & 11.170 & 3.751 & 1,281 & 225 & 297 & 50.252 \\
\hline Cuzcatlín & 25.449 & 8.899 & 2.402 & 167 & 0.046 & 4.020 & 694 & 244 & 681 & 48.602 \\
\hline Ahuachapán & 24.794 & 9.633 & 1.218 & 394 & $14.4 \% 9$ & 7.866 & 573 & 856 & 555 & 60.388 \\
\hline Morazân & 14.143 & 5.670 & 714 & 1.35 & 8.411 & 4.038 & 2.339 & 203 & 159 & 35.812 \\
\hline San Vicentc & 16.180 & 8.491 & 1.236 & 575 & 8.430 & 1.589 & $\$ 42$ & 24.3 & 140 & 37.426 \\
\hline Cabarias & 15.054 & 3.680 & 578 & $6 \times k$ & 4.777 & 4.075 & .364 & 306 & 935 & 30.375 \\
\hline TOTAL & 605,775 & 287.811 & 59.843 & 9.431 & 240,451 & 83.520 & 33.510 & 12.827 & 12.109 & 1.345 .277 \\
\hline
\end{tabular}


PORCENTAJE DE VOTACION PARA DIPUTADUS P(IR DEAPARTAMENTIO (marzo 1994)

\begin{tabular}{|c|c|c|c|c|c|c|c|c|c|c|}
\hline & ARENA & FMLN & $\mathrm{CD}$ & MNR & $\mathrm{PDC}$ & $\mathrm{PCN}$ & $\mathrm{MU}$ & MSN & MAC & $\begin{array}{c}\text { VOTOS } \\
\text { VALIDOS }\end{array}$ \\
\hline San Salvador & 44,80 & 29.49 & 5.63 & 0.61 & 11.37 & 3.91 & 2.85 & 0.80 & 0.5 .5 & 100,00 \\
\hline Santa Ana & 43,92 & 21.46 & 4,44 & 0.61 & 20.98 & 5.22 & 1.70 & 0.94 & 0.74 & 100,00 \\
\hline San Miguel & 44,63 & 15,04 & 3,84 & 1.14 & 23.57 & 6.03 & 2,95 & 1.66 & 1.13 & 100,00 \\
\hline La Libertad & 47,87 & 21.93 & 4,79 & 0.87 & 15.61 & 4.38 & 2.77 & 0.64 & 1.15 & 100,00 \\
\hline Usulután & 44.09 & 15.94 & 5.58 & 0.76 & 21.13 & 5.91 & 2.57 & 2.64 & 1.37 & 100,00 \\
\hline Sonsonate & 43.10 & 16,71 & 4.79 & 0.6 .3 & 23.4 .5 & 7.65 & 1.72 & 0.89 & 1.07 & 100,00 \\
\hline La Unión & 45,57 & 6.83 & 3,71 & 0.51 & $3(1 .(5)$ & $7 . .31$ & 3.24 & $1.0,3$ & 1.71 & 100,00 \\
\hline LaPaz & 46.59 & 15.96 & 2,27 & 0.39 & 20.34 & 10.73 & 2.37 & 0.70 & 0.64 & 100,00 \\
\hline Chalatenango & 45,05 & 18,89 & 2,44 & 0.34 & 22.23 & 7,46 & 2.55 & 0.45 & 0.59 & 100,00 \\
\hline Curcatlán & 52,36 & 18.31 & 4.94 & 0.34 & 12.44 & 8,27 & 1.43 & 0.50 & 1.40 & 100,00 \\
\hline Ahuachapán & 41,06 & 15.95 & 2.02 & 0.65 & 24.01 & 13,03 & 0.95 & 1.42 & 0.92 & 100,00 \\
\hline Morazán & 39,49 & $15,8.3$ & 1.99 & $0.3 x$ & 23,49 & 11.28 & 6.5 .3 & 0.57 & 0.44 & 100,00 \\
\hline San Vicente & 43.23 & 22.69 & 3.30 & 1.54 & 22.52 & 4.25 & 1.45 & 0.65 & 0.37 & 100,00 \\
\hline Cabañas & 49.56 & 12.12 & 1,90 & $2 .(x)$ & 15.73 & 13.42 & 1.20 & 1.01 & 3.08 & 100.00 \\
\hline TOTAL & 45,03 & 21,39 & 4,45 & 0.70 & 17,87 & 6.21 & 2,49 & 0.95 & 0.90 & 100,00 \\
\hline
\end{tabular}

\section{CUADRO N 6}

DISTRIBUCION DE DIPUTADOS POR PARTDO

(coclentes y residuos)

(elecciones de1994)

\begin{tabular}{|c|c|c|c|c|c|c|c|c|c|c|c|c|c|c|c|c|c|c|c|}
\hline & \multirow{2}{*}{\multicolumn{2}{|c|}{ ARENA }} & \multirow{2}{*}{\multicolumn{2}{|c|}{ FMLN }} & \multirow{2}{*}{\multicolumn{2}{|c|}{$C D$}} & \multicolumn{2}{|c|}{ MNA } & \multicolumn{2}{|c|}{$P D C$} & \multicolumn{2}{|c|}{$\mathrm{PCN}$} & \multicolumn{2}{|c|}{ MU } & \multicolumn{2}{|c|}{ MSN } & \multicolumn{2}{|c|}{ MAC } & \multirow{2}{*}{$\begin{array}{l}\text { TOTAL } \\
\text { DIPUT. }\end{array}$} \\
\hline & & & & & & & & $\cdots$ & $\cdot$ & $\cdots$ & $\cdot$ & & & $\cdots$ & $\bullet$ & $\cdots$ & & $\cdots$ & \\
\hline San Salvador & 7 & 0 & 4 & 1 & 0 & 1 & 0 & 0 & 1 & 1 & 이 & 1 & 0 & 0 & 0 & 0 & 0 & 0 & 16 \\
\hline Santa Ana & 2 & 1 & 1 & 0 & 0 & 0 & 0 & 0 & 1 & 0 & 0 & 1 & 0 & 0 & 0 & 0 & 0 & 0 & B \\
\hline San Mlguel & 2 & 0 & 0 & 1 & 0 & 0 & 0 & 0 & 1 & 0 & 0 & 1 & 0 & 0 & 0 & 0 & 0 & 0 & 5 \\
\hline La Libertad & 2 & 1 & 1 & 0 & 0 & 0 & 0 & 0 & 0 & 1 & 0 & 0 & 0 & 0 & 0 & 0 & 0 & 0 & 5 \\
\hline Usulután & 1 & 1 & 0 & 1 & 0 & 0 & 0 & 0 & 0 & 1 & 0 & 0 & 0 & 0 & 0 & 0 & 0 & 0 & 4 \\
\hline Sonsonate & 1 & 1 & 0 & 1 & 0 & 0 & 0 & 0 & 0 & $t$ & 0 & 0 & 0 & 0 & 0 & 0 & 0 & 0 & 4 \\
\hline La Unión & 1 & 1 & 0 & 0 & 0 & 0 & 0 & 0 & 0 & 1 & 0 & 이 & 0 & 0 & 0 & 0 & 0 & 0 & 3 \\
\hline La Paz & 1 & 0 & 0 & 1 & 0 & 0 & 0 & 0 & 0 & 1 & 0 & 0 & 0 & 0 & 0 & 0 & 0 & 0 & 3 \\
\hline Chalatenango & 1 & 0 & 0 & 1 & 0 & 0 & 0 & 0 & 0 & 1 & 0 & 0 & 0 & 0 & 0 & 0 & 0 & 0 & 3 \\
\hline Cuzcatián & 1 & 1 & 0 & 1 & 0 & 0 & 0 & 0 & 0 & 0 & 0 & 0 & 0 & 0 & 0 & 0 & 0 & 0 & 3 \\
\hline Ahuachapán & 1 & 0 & 0 & 1 & 0 & 0 & 0 & 0 & 0 & 1 & 0 & 0 & 0 & 0 & 0 & 0 & 0 & 0 & 3 \\
\hline Morazán & 1 & 0 & 0 & 1 & 0 & 0 & 0 & 0 & 0 & 1 & 0 & 0 & 0 & 0 & 0 & 0 & 0 & 0 & 3 \\
\hline San Vicente & 1 & 0 & 0 & 1 & 0 & 0 & 0 & 0 & 0 & 1 & 0 & 0 & 0 & 0 & 0 & 0 & 0 & 0 & 3 \\
\hline Cabakas & 1 & 1 & 0 & 0 & 0 & 0 & 0 & 0 & 0 & 1 & 0 & 0 & 0 & 0 & 0 & 0 & 0 & 0 & 3 \\
\hline Jancha Nacione & 9 & 0 & 4 & 1 & 0 & 0 & 0 & 0 & 3 & 1 & 1 & 0 & 0 & 1 & 0 & 0 & 0 & 0 & 20 \\
\hline TOTAL & 32 & 7 & 10 & 11 & 0 & 1 & 0 & 0 & 6 & 12 & 1 & 3 & 0 & 1 & 0 & 0 & 0 & 0 & 84 \\
\hline
\end{tabular}

Nota: - corresponde a diputados electos por cociente

- corresponde a diputados electos por residuo 


\section{CUADRON 7}

ELECCIONES DE ALCALDES

MUNICIPIOS DONDE SE INCRIULERON CANIIDATOS

\begin{tabular}{|c|c|c|c|c|c|c|c|c|c|c|c|c|c|c|}
\hline & $\begin{array}{l}\text { MUNICl- } \\
\text { PIOS }\end{array}$ & ARENA & FMLN & $C D$ & MNR & $\begin{array}{l}\text { FMLN } \\
\text { (D) }\end{array}$ & $\begin{array}{l}\text { FMLN } \\
\text { MNR }\end{array}$ & $\begin{array}{c}\text { MNR } \\
\text { Cl) }\end{array}$ & $\begin{array}{c}\text { FMLN } \\
\text { Cl)-MNR }\end{array}$ & PDC & $\mathrm{PCN}$ & $M U$ & MSN & $\overline{M A C}$ \\
\hline San Salvador & 19 & 19 & 19 & 17 & 16 & 4 & R & 11 & 3 & 19 & 19 & 14 & 15 & 5 \\
\hline Sanva Ann & 13 & 13 & 13 & 11 & 5 & 12 & 0 & () & 0 & 13 & 13 & 8 & 7 & 6 \\
\hline San Miguel & 20) & 20 & in & 13 & (I) & 4 & 11 & 4 & () & 20 & 20 & 12 & 9 & 9 \\
\hline La Libertad & 22 & 22 & 22 & h & In & 1 & ? & 1 & 0 & 22 & 22 & 12 & 9 & 18 \\
\hline Usululín & 23 & 23 & 23 & 14 & 3 & 2 & (1) & 0 & 0 & 23 & 21 & 10 & 13 & 10 \\
\hline Sonsonste & 16 & 16 & 14 & 11 & 3 & 3 & 1 & 0 & 0 & 16 & 16 & 8 & 7 & 9 \\
\hline La Unión & 18 & 18 & 14 & 15 & 7 & 0 & 0 & 0 & 0 & 18 & 17 & 10 & 11 & 11 \\
\hline LaPaz & 22 & 22 & 17 & 4 & 1 & 0 & 0 & 0 & 0 & 19 & 22 & 8 & 4 & 11 \\
\hline Chalatenango & 33 & 33 & 33 & 1 & 0 & 1 & 0 & 0 & 0 & 31 & 26 & 3 & 1 & 3 \\
\hline Curcatlin & 16 & 16 & 16 & 16 & 2 & 16 & 0 & 0 & 0 & 16 & 15 & 2 & 3 & 11 \\
\hline Ahunchapin & 12 & 12 & 10 & 5 & 2 & 0 & ? & () & n & 12 & 12 & 6 & 12 & 4 \\
\hline Monzin & 26 & 26 & 21 & 4 & 0 & n & 11 & n & 11 & 25 & 26 & 33 & 1 & I \\
\hline Sun Vicente & 13 & 13 & 12 & II & 1 & $R$ & 0 & 0) & 0 & 13 & 13 & 4 & 2 & 2 \\
\hline Cabahas & 9 & 9 & 9 & 3 & 7 & 0 & 0 & 1 & 0 & 9 & 9 & 2 & 2 & 5 \\
\hline TOTAL & 262 & 262 & 241 & 131 & 67 & 51 & 13 & 7 & 3 & 256 & 251 & 122 & 96 & 105 \\
\hline$\%$ & & 100,0 & 92,0 & 50,0 & 25,6 & 19.5 & 5.0 & 2.7 & 1,1 & 97.7 & 95.8 & 46,6 & 36,6 & 40,1 \\
\hline
\end{tabular}

\section{CUADRO N98}

\section{ELECCIONES DE ALCALDES}

NUMERO DF MUNICIPIOS GANADOS

\begin{tabular}{|c|c|c|c|c|c|c|c|c|c|c|c|c|c|c|c|}
\hline & $\begin{array}{c}\text { MUNICI. } \\
\text { PlOS }\end{array}$ & ARENA & FMiN & & & MNR & $\begin{array}{l}\text { Fill. } \\
\text { (I) }\end{array}$ & $\begin{array}{l}\text { FNI.N } \\
\text { MNR }\end{array}$ & $\begin{array}{c}\text { MNR } \\
\text { (.I) }\end{array}$ & $\begin{array}{c}\text { FMIN } \\
\text { (:)-MNK }\end{array}$ & $\mathrm{PAC}$ & PC:N & MU & MSN & MAC. \\
\hline San Salvador & 19 & 15 & & 2 & () & 0 & 0 & 11 & $n$ & 0 & 0 & 2 & 0 & 0 & 0 \\
\hline Sania Ara & 13 & 10 & & 0 & 0 & 0 & 0 & 0 & (1) & (1) & 1 & 0 & 0 & 0 & 0 \\
\hline Sun Miquel & 20 & 16 & 0 & 0 & 0 & 0 & 0 & 0 & 0 & 0 & 3 & 0 & 0 & 0 & 1 \\
\hline La libertad & 22 & 21 & 0 & 0 & 0 & 0 & 0 & 0 & 0 & 0 & 1 & 0 & 0 & 0 & 0 \\
\hline Usulutín & 23 & 18 & 0 & 0 & 0 & 0 & 0 & 0 & 0 & 0 & 4 & 1 & 0 & 0 & 0 \\
\hline Sonsonate & 16 & 13 & & 0 & 0 & 0 & 0 & 0 & 0 & 0 & 3 & 0 & 0 & 0 & 0 \\
\hline La Unión & 18 & 15 & 0 & 0 & 0 & 0 & 0 & 0 & 0 & 0 & 2 & I & 0 & 0 & 0 \\
\hline La Paz & 22 & 18 & 0 & 0 & 0 & () & 0 & n & n & 0 & 2 & 2 & 0 & 0 & 0 \\
\hline Chalatenango & 33 & 25 & & 4 & 0 & 0 & 0 & 0 & () & () & 3 & 1 & 0 & 0 & 0 \\
\hline Cuzcation & 16 & 14 & 0 & 0 & 0 & 0 & 1 & 0 & () & 0 & 0 & 1 & 0) & 0 & 0 \\
\hline Ahuachapin & 12 & 10 & & 0 & 0 & 0 & (1) & 0 & n & 0 & 2 & 0 & () & 0 & 0 \\
\hline Morazín & 26 & 17 & s & 5 & 0 & 0 & 0 & 0 & 0 & 0 & 3 & 1 & 0 & 0 & 0 \\
\hline San Vicente & 13 & 8 & 1 & 1 & 0 & 0 & 1 & () & 0 & 0 & 3 & 0 & 0 & 0 & 0 \\
\hline Cabonias & 9 & 7 & I & I & 0 & (1) & 11 & 0 & 1) & (1) & 0 & 1 & 0 & 0 & 0 \\
\hline TOTAL & $26 ?$ & 2017 & 1.3 & 3 & 0 & 0 & $?$ & i1 & 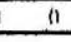 & i) & 39 & 10 & 0 & 0 & 1 \\
\hline$\%$ & & 79,0 & 5.0 & 0 & 0.0 & 0.0 & $0, R$ & 0.0 & 0,11 & 0,0 & 11,1 & 3,8 & 0.0 & 0.0 & 0.4 \\
\hline
\end{tabular}




\section{CUADRO N 9}

MUNICIPIOS DONDE ARENA SACO MAS DE, 50\% Y DONDE LA TRENZA PUDO GANAR (elecciones municipales, marzo 1994)

\section{ARENA COALICION TRENZA}

\begin{tabular}{lrrr}
\hline San Salvador & 2 & 3 & 12 \\
Santa Ana & 3 & 0 & $9 * *$ \\
San Miguel & 5 & 1 & $12^{* *}$ \\
La Libertad & 13 & 0 & 5 \\
Usulután & 4 & 1 & 10 \\
Sonsonate & 4 & 0 & 6 \\
La Unión & 8 & 0 & $4^{* * *}$ \\
La Paz & 9 & 0 & $6^{* *}$ \\
Chalatenango & 11 & 4 & 14 \\
Cuzcatlán & 11 & 1 & 3 \\
Ahuachapán & 1 & 0 & $5^{* *}$ \\
Morazán & 5 & 5 & $16^{* *}$ \\
San Vicente & 3 & 2 & 9 \\
Cabantas & $3 *$ & 1 & 3 \\
& & & 114 \\
\hline \multicolumn{1}{c}{ TOTAL } & 82 & 18 & 18 \\
\hline
\end{tabular}

*: El partido ARENA logró más del 50\% cn la callccera dcparlamental.

**: La Trenza pudo haber ganado la cabecera departamental.

***: El PDC por sí solo ganó la cabccéra departamental. 